\title{
鋼及:銑鐵中の硫黄分析法に就て
}

\author{
十河浩

\section{ON THE DETERMINATION OF SULPHUR IN STEEL AND PIG IRON} \\ Hiroshi Sogõ.
}

SYNOPSIS :- The present writer carried out several researches on the subject from the accuracy and easiness of the practical veiw pts, and suceceeded to get the reliable results to be shown in the following summary:-

(1) In case of carbon and special steels, the oxidation method by nitric and hydrochloric acid is the most reliable process to get the accurate results while the evolution method is used to show very of ten too low results by the incomplete solubility.

(2) In case of pig irons, the evolution method is only useful to estimate small part of sulphur in it and most part of sulphur is remained in the evolution flask.

The application of the oxidation method by nitric and hydrochloric acid nearly always gives low results, and in such a case considerable amount of sulphur is found unestimated in the remaining residue with silica and graphite.

Then in this method the residue must be re-examined for sulphur; although the treatment is very tedious and liable to do failure.

Therefore in this work, the present writer tried and succeded to determine the total sulphur in pig iron by fusion method with the mixture of sodium peroxide" and sodium carbonate $(1: 1)$.

And he has found this method is the most reliable and universally applicatule one for determination of sulphur in pig iron

Now then the writer is wanted to add the experimental results with three different methods to emphasize his researches. which were applied to the Swedish pig irons.

$$
\frac{\mathrm{s} \%}{\text { Brand }}
$$

Ä. J. \& C. Bofors

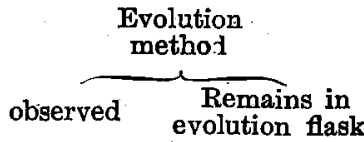

$$
0.007
$$$$
0.008
$$
Remains in
evolution flask 0.027 0.027

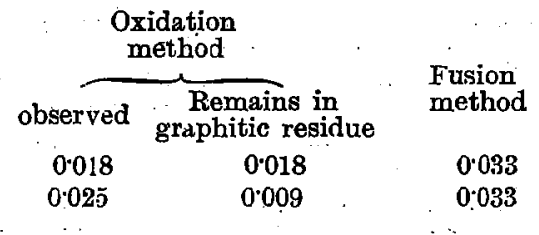

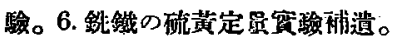

緒 言

\section{第 I 章 炭素鋼及特殊鋼の硫黄定量に就て}

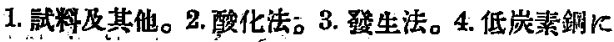

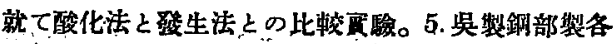

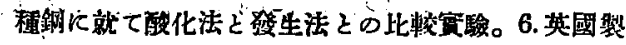

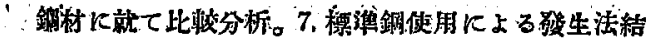
果の修正に就て。

第II意銑鐵の硫黃定量に就て１．訊料及其の

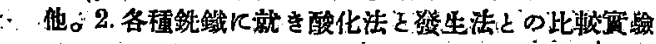

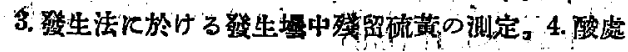

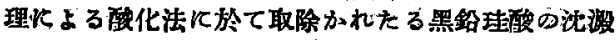

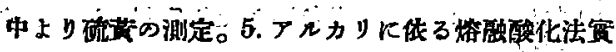

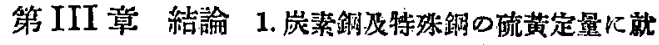

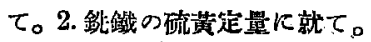
緒霉

鐵鎆に含まれる硫黃の定量に開する研究は極め て多数に上り其の定量方法亦多程多漛に亘る，諸、 說區※であつて、之を一般的に應用し得る標潐分 析法なるもの小存在に疑問を绥くものである。而 して現狀察際に於ても各所各樣の定量法を探用し て統一なく・其中分析值に著しく罂異を生するて 
との多んのは一般に知られた事算である。 從つて本呼究の主目的は工䅈分析的立埸よりし て、正碓であり且實用化し得る分析法を探枈せん とするにある。

多樣な鐵鋼の硫黃分析法も之を大別して次の 2 項に分けられると思ふ。

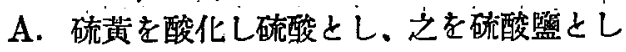
て定量考行子酸化法。

B. 硫黃を還元して硫化水䕀瓦斯として發走

し、之を定量する發生法。

而して現今一般に用ひられるものとしては、酸化 法では硧酸及監酸による所謂汒水酸化法最子多 く、次庄パンバー法、臭䋕酸化法、熔融法等で。 發生法では監酸により硫化水菜瓦斯として發生し 之を亞鉛監或はカドミウム監に作用させ、硫化物 として定量する刍ード滴定法寽であら5。

是等の网方法の正熦度に對する世論を概括すれ ば、酸化法では其の處理法操作传の細き點に就て は夫之異論あり、且此较的操作䄍雜で長特間を姴 するる、大體に於て鐵鋼中硫㦈の全量を求め得る と洘へられ、發生法では操作簡易であり、短時間

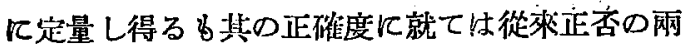
諭があつて一定して居ない。

是等に關しては先に發表された、既往文献の概

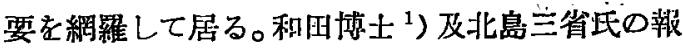
文中に記述されて扂る、而して期の後に墢表され た 2.3 文献を記せ隹、前記と同じ研究で北島三 省氏 ${ }^{2}$ ) は鐵の含さ硫黄の全量を求むるには弥生 法では不確算である、之は總ての如何なる鐵にで

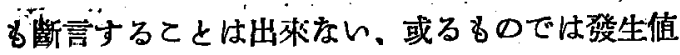

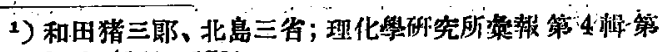

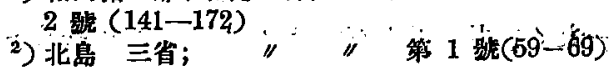

と酸化法值の一致しないとは限らないが、之は稀 であうて、大多數の場合二敨しないてとを指摘し 斯かるるのでは發生薷中に硫黃が殘留するてとを 蕒證し、是等は試料の会硫狀態に支配されるるの であると述べて居る。

茂木武雄氏 ${ }^{1}$ ) 真野惣次郎氏 4 足田氏の 亞鉛 マルガム說を探り、改良筫驗によつて發生法で鐵 鍓印硫黃の總量を求的得ることを諭迅した。

辰谷川熊彥氏 ${ }^{2}$ ) 石賀亮教氏，內藤達氏は普通 銑鐵、普通鋼、特殊鋼 (2,3 を除き)では难生法 で總量を求め得るる。特殊鋎鐵及特殊鋼中 2.3 は發生法では不適當ですすて酸化法に據るへしと して居る。

A. Kling ${ }^{3}$ ) 及 A. Lassieur は銑鐵反就て 㥅生法では完至なる定量は容易でないが、特别な る注意の許に嚴密な操作を行ひ正確な值を舉げ得 るし、鋼では容易に正しき發生值を示すと述へ。

K. K. Jarvinen 4) は精密な筫驗の結果鐵中 の正しき硫黄量を求むるには息素酸化後熔融によ る酸花法を提唱した。

更に北島三省氏 ${ }^{5}$ ) は發生法で鐵の硫黄を定量 する際、嵊中に起る反應に就て各種の賓驗に依り 硫酸銅、硫酸鐵の狀態で鐵中に存在する場合は硫 化水素として發生するてとなく、不溶解殘留物若 は溶液として發生暴中に殘り、硫化銅及遊離硫黃 は熱濃監酸上鐵上の作用に因り硫化水素に化成す るも反應は比校的䌊徐に行はれるととを實登し to

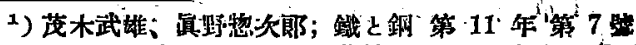

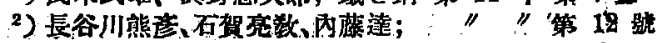

3) A. Kling \& A. Lassieur; J. Iron \& Steel Institute 1926. No. $\mathrm{Tt}^{\prime}(676)$

*) K. K. Jarvinen; ‥ 1927, No. I (981)

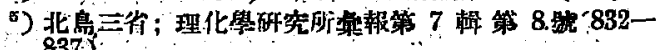


長谷川熊彦氏 ${ }^{1}$ ) は前編 ${ }^{2}$ )に引續き鉄鐵中の硫 黄に就て珪素の多的鼠鉄鐵で滿俺量 $\theta .3 \%$ 以下の

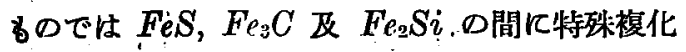
合物を生成する、從て斯かるるのを䇫生法で處理 するときは監酸に對して不溶解性硫黄化合物とし て殘り全硫黄量を現さないから、是等の特殊銃鐵 では $900^{\circ} \mathrm{C}$ で燒鏣した後發生法を施行して全硫 黃を定量せねばならぬ．而して白銃にて不溶解性 硫黄化合物を認めす。、又海鼠鉑鐵中には此の複化 合物存在するる之を再熔解した場合には少ないて とを認めた。

井上克民氏 ${ }^{3}$ )は鼠銈鐵の滿俺量の少ないるの は酸化法值に比し發生值は低く、白銃では䩗俺少 量なるのる兩法結果一致する、然るに珪素を增加 して鼠銈鐵化するに從ひ發生值怟下する、是等 は黑鉛の爲に FeS が機械的に包まれた狀態とな

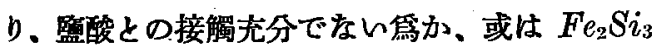
が $F e S$ と共に鐵中に固溶體として存し、監酸に 對して大いに溶解度を異にする第なるへく、燒鈍 が發生值を良くする影響より觀て後者の場合上見 るも詿りなかるへしと述べ、更に燒鈍に估る效果 は影著であり、發生值が酸化法の值に接近するて とを指摘し、燒鈍の溫度及時間は銑鐵の成分及其 の鉄鐵の揢融狀態上 D凝固し常溫に至る冷却速度 等に關係し、滿俺少く珪素多いるのは高溫で長時 間を要し滿俺多く珪素少いるのは低溫で短時間で 良しことを䆩證した。

少 F. T. Sisco 氏 ${ }^{4}$ ) の著書に電氣鋼。坩堝鋼

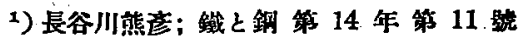

2) 前揭

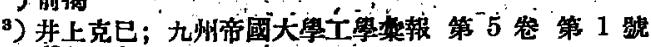
(31-40)

4) F. T. Sisco; Technical analysis of steel and steel wo ks materials. 1923 (84-85. 203-212. 311317)
は發生法では確に低値を示す故に發生值を特殊の 方法で修正することに依り真の硫黃量に近似の値 を得ることが出来ると述べて居る。

斯くの如く夫そ異なつた意見が報ぜられ其の何 れを真なりとる斷定するてとを許されぬ，

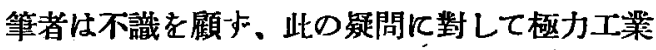
分析的實際に重きを畧き、各種の鐵鋼に就て實驗 を施行し、正確な標準分析の探究に努め。炭素鋼 及特殊鋼の硫黄定量法抹に銑鐵の硫黄定量法に章 を分ちて記述した。

本研究は筆者本務の傍之を行つたるのであり。 文献に接する機會る少なく、古分な實驗を行ふ餘 㗇るなかつたので徽底しない點、獨斷に傾ける點 等多く、不完全なるのであるが、之を公表して諸 賢の御教示を仰ぐ次第である。

\section{苐 I 章 峞素銅及び特殊銅の 硫橫定量に就て}

1. 試料及其の他 鋼の硫黄定量資驗試料として 2. 3 項には米國標潐局發賣の炭素鋼及特殊鋼 9 種. 4.5 項には针海軍工廠製鋼部製各種の鋼、 6 項には英國毘新、トーマス・フアース祊及安社 製の鋼試料を用ひた。

米國標潐試料の各成分は第 1 表の通りである。 製鋼部製鋼材及英國試料の成分は後の各貝驗の 項に併記する。

實驗に當つては米國標淮試料は細粉とし其の他 は細く薄き錐粉として使用した。

其の他加熱裝置は主として電熱砂浴を用ひ、瓦 斯砂浴も併用したが、此の場合は特に装置に注意 して瓦斯ब影響なをを確めて用ひた。使用試菜は 常に其の純度を检定して純品を用いたるは勿論。 各實驗定量には總て宾試驗を行うて定量值に誤り 


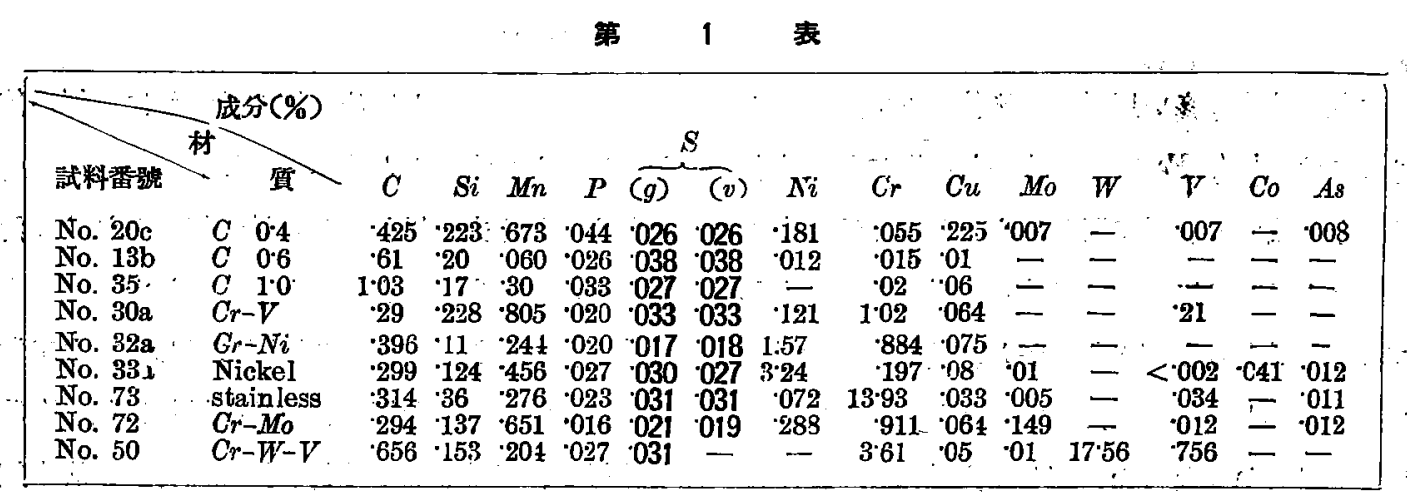

（米國標準局分析表平均值）

（主として平均值を报萃 $し$ 其の他の分析結果及分析者氏名等は略す）

なきを期した。

2. 酸化法 酸化による重量定量法は一般に正碓 な結果を示すを信ぜられて居るが、酸化割及其の 處理法は種々異るるのがある。而して孷素銅及特 種鋼に對して一般に應用卞ることが出隶、且現今 廣く用ひられるすのは、硝酸酸化法或は王水酸化 法であら5、故に体研究で为此の方法に據つた。 酸化法實驗其囚一では溶解酸、硫酸バリウムの沈

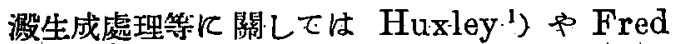
Ibbotson $^{2}$ ).の推獎した操作を探用し必要に應じ て若干改めた。

郎ち概要を記せば、溶解酸としては先つ硝酸に より溶解せしめ、溶解不充分を場合を考虑して硝 酸添加後少量の監酸を滴下した、其の割合は約硝 酸 3 : 監酸 1 である。不銹鋼、高速度鋼の如く溶 解困難なるものでは少しく醅酸の量を增加した。

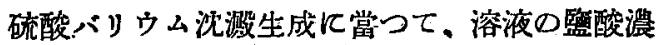
度は酸の稀薄に過ぐる恐れ及酸洤厚に過ぐる恐れ を防止する目的で、豫め監酸添玑の量を制限し一

1) T. F. Rooney; J. Iron \& Steel Institute 1921 No. I (339-353).

2) Fred Ibbotson; The Chemical analysis of steel : Works materials: 1920 . (65 75.)

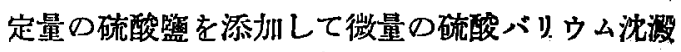
の生成を助け、且其の處理を容易ならしめた。

特に本法 ${ }^{1.2}$ )、专選んだのは第二鐵監の監酸溶液 に對する硫酸バリウムの溶解量相當見るべをるの 汃ある報文 ${ }^{3}$ ) もあり、賽際に微量なる鋼中の硫 黄の定量に賞つて此の傾向老認められた䳕、硫酸 籃を豫め使用するてとによつて此の缺陷唋くて とが出氷ると考へたからである。

酸化法實驗其 2 では筫驗其 1 で第二鐵監溶液 から沈澱させたのに對し、第二幽㹂を亞鉛で還元 して第一鐵壁と.して溶液から硫酸バリウムを沈被 させた。

酸化法實驗其:

(A) 分析操作一一試料 5 瓦をビーカ、に㹃取.

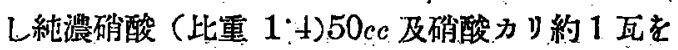
州一溶解L、次に純濃監酸（比重 1.18) 15 乃至 $20 c c$ を注加し試料を完全に溶解酸化する、此の とき必吉標潐鋼試料（硫黄量既知の）を添付し置 く、反應終らば砂浴上で徐々に蒸發乾涸を行ふ。

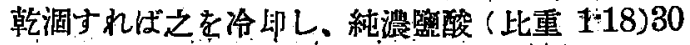

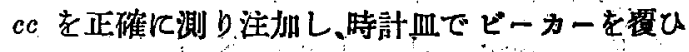

$$
\text { 1)、 } \left.{ }^{2}\right) \text {, }{ }^{3} \text { 前揭 }
$$


础浚上で溶解し次に徐にに蒸發して 11 乃至 13 ec 凡液を減少したとき溫湯 $100 c c$ で稀释し、滤過

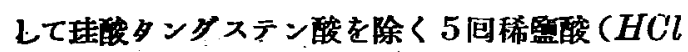
$10 c c: H_{2} O 600 c c$ )で洗淮し其の淐液に標準硫酸力

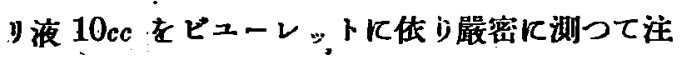
加七:次に篮化バリウム溶液 $10 \mathrm{cc}$ を加人て全液量 を500ec となし良く䚌讲して砂浴上で加温する。

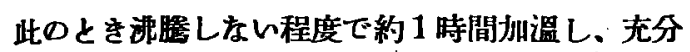

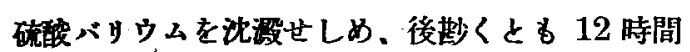

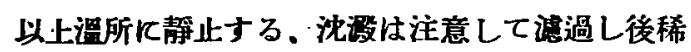
覀酸 $\left(\mathrm{HCl10} c \mathrm{c}: \mathrm{H}_{2} \mathrm{O} 600 \mathrm{cc}\right.$ ) 老以て鐵監衣除去 上. 蒸溜水で酸を洗㴪す。硫酸バリウムは㴓紙と 共に磁䌘㘫堝內に入れ灼熱して乾燥器に移し冷却 し科量する。

・斯くして標潐鋼試料より得な硫酸バリウムの重 量から標淮鋼の既知硫酸バリウムの重量を诚市。 此の差量は標淮硫酸カリから沛鼡した硫酸バリウ 么量よ試菜のプランクの硫酸バリウム量である。 此の合量を各可铪試料の硫酸ハリウム重量から控 除した残量から硫带量を算出する。之が各試料の 合む硫黄量である。

(B) 試 秋

標潗硫酸カリ溶液: 一一純硫酸カリ1·36 瓦を蒸 溜水に溶解し $1,000 \mathrm{ec}$ とする。

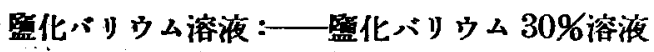
とし、证過して不溶解残渣を除いたるのを用ふ。 磌酸バリウム沈澄純白ならさるときは手金㘫城 に取りンーダ灰を加へて塎融し再沈溜を行ふか或 は再定量を行方。

本法に依つて第 1 表の米國標潗銅を虑理した絬 果壮第:2表中の其のーーである。 酸化法筫驗其 2
(A) 分析操作：一一診料万瓦をどーカーに採

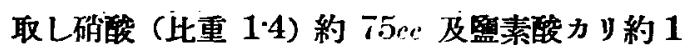

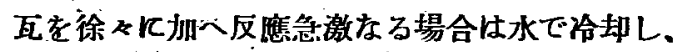
分解終了後加熱蒸發してて液量を約 $10 c c$ とする。 冷却後辟酸(比重 $1-18$ ) 的 $30 \mathrm{ec}$ を㧈人之を磁製血

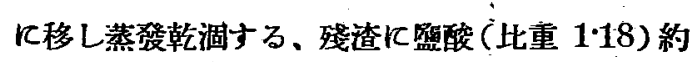

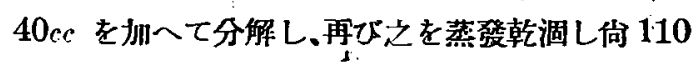
${ }^{\circ} \mathbf{C}$ で 30 分間位加熱する。

冷却㘼監酸 (1:1) 約 $60 c \dot{c}$ を扒靜かに熱して 溶解し水 $50 \mathrm{cc}$ を招人文約 5 分間意沸する、次

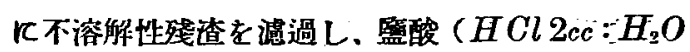
100ce) で洗鿟する、滤液は再で表面に皮膜を生 する迄蒸發して之に警酸 (比重 1.18 ) 約 $20 \mathrm{cc}$ 度

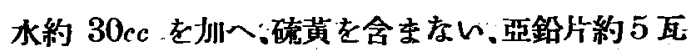
を加へて靜かに加熱し、第二鐵を第二鐵に還元し

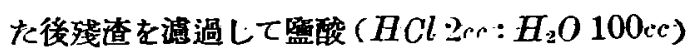
で充分に洗澡する、次に液を約 $250 \mathrm{cc}$ に稀稏して 液㵋 $70^{\top} \mathrm{C}$ と監化バリウム溶液 $(10 \%)$ 約

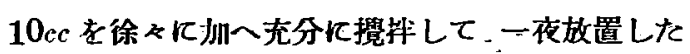

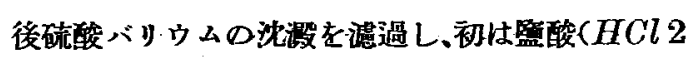
$\left.c c: H_{2} O 100 c c\right)$ で洗淮し、次に價水で洗淮する。

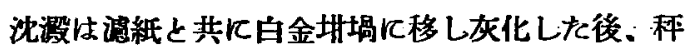
量し硫黄量を算出する。

若し硝酸及監素酸カリで分解不完全な陚料では 約 25rc 以下の監酸比重.118) を掍じて之を分 解する。

以上の操作で米國䅺潐試料を定量した值は第 2 表其 2 である。

第 2 表の結果では其 1、其2はよく一致して 居る（No. $30 \mathrm{a} C i-V$ 銅では試料が少量であつ た篇其2の嘪验を充分行ふてをが出来なかつたの で、少しく低値を示すも試料多量ならば其1 と同 


\begin{tabular}{|c|c|c|c|c|}
\hline & 試 料 & & \multicolumn{2}{|c|}{ 酸化法 S\% } \\
\hline 欺 & 號 & $\begin{array}{l}\text { 米國標漼 } \\
\text { 局平均值 } \\
\mathrm{S} \% \quad(\mathrm{~g})\end{array}$ & 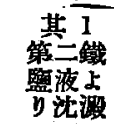 & 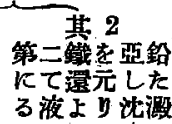 \\
\hline $\begin{array}{l}\text { No.2Cc } \\
\text { No.13b } \\
\text { No.35 } \\
\text { No.30a }\end{array}$ & $\begin{array}{ll}C & 0.4 \\
C & 0.6 \\
C & 1.0 \\
C r-V\end{array}$ & $\begin{array}{l}.026 \\
.038 \\
.027 \\
.033\end{array}$ & $\begin{array}{l}.026 \\
.040 \\
.027 \\
.033\end{array}$ & $\begin{array}{l}.025 \\
.041 \\
.029 \\
.026\end{array}$ \\
\hline $\begin{array}{l}\text { No.32a } \\
\text { No.33a } \\
\text { No.73 } \\
\text { No.72 } \\
\text { No.50 }\end{array}$ & $\begin{array}{l}C_{r}-N i \\
N i \\
\text { stainless } \\
C r-M o \\
C r-W^{-}-V\end{array}$ & $\begin{array}{l}.017 \\
.030 \\
.031 \\
.021 \\
.031\end{array}$ & $\begin{array}{l}.019 \\
.031 \\
.031 \\
.022 \\
.032\end{array}$ & $\begin{array}{l}.018 \\
.028 \\
.028 \\
.021 \\
.035\end{array}$ \\
\hline
\end{tabular}

樣な値を得られると思ふ)。

郎ち硝酸及監酸による酸化法では、第二鐵監塎 液永ら硫酸バリウムを沈澱させを場合も、第二鐵 を第一鐵に還元した溶液から沈澱させた場合も共 に一政した分析值を得られることが解つた：而し て 米國標準局酸化法平均值とも上く一政して居 る、硝酸及監酸几依る酸化法では炭素鋼及特殊鋼 中の正確をる硫黃量を求め得ると推斷することが 出來る。

而して是等二つの操俳に就て見るに第二鐵監液 から沈搌する、本寶驗の操作は簡單であつて、第 二鐵を第一鐵沉還元する操作に比へて相當短時間 に行ふととが出來る、結果に於ても常に正敉な值 を得易い便がある。特に一時に種類を異にした多 數の鋼を取扱ふ心場合には最も適當である。

第二鐵を、第一鐵に還元した溶液から沈搌する 操作で壮比较的複雜ですり，長時間を要し硫酸パ リウムの沈澱不克分な場合を生じ易い䉆. 時とし ては稍々低分析倬を示す傾向がある。

及一時に多數の鋼を處理する場合不便である。 是等兩方法共周到なる注意と、相當の熟練とを 要するのは論を俟をない。

3. 發生法 鋼中硫黃を還元して硫化水素瓦斯と して週宜の處理に传つて比色。重量或は容量の諸
方法で定量する媇生法中、監酸で硫化水素瓦斯 して發生し、之を亞鉛監或ばガミゥム監に吸收 させて硫化物として、之をヨート滴定に传つて定 量する容量法が最る優れた当の上考へられ、且一

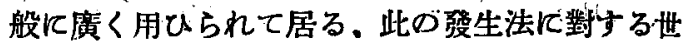
論は既に述べた通りである。發生法で爾タ議論の 生する主な點及是等に對する既往の處理法孝䀧计 ると次の逝りである。

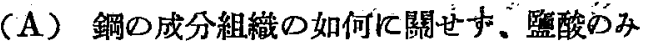
にて發生を行ふが故に，如何まる濃度の酸を用ふ へきかに就て、稀監酸說、濃監酸說がある、而して 適當な酸濃度で果して完全を硫黄を發生する事が 出來るや否やは設生法の最主主要な點であら5。

（B）發生嚗內䨌圍策を。硫化水素弡生に有利 とし、且之を完全に吸收液に揆る目的で，炭酸瓦 斯或は水素瓦斯を發生嚗に揆つて居る。

（C）鋼自身孝何等加の方法で 發生し易的狀熊 に置く目的で發生處理に先達て燒鈍處理が行仗れ て居る。

(D) 監酸の還元を助ける目的で、補助劑とし て亞鉛、アルミ゙シム、錫或は亞鉿アマルガム等 を筂生嚗中に添加して居る。

（E） 發生瓦斯中に 硫化水素以外 $ه$ 硫黄化合物 を合むと云はれ、之に對する處置として發生瓦斯 を赤熱管に通過して硫化水素以外の瓦斯を分解し て居る。

是等の處理法の要否に就ても稞々說かれたもの がある。

T. G. Elliot ${ }^{1}$ )は浱辟酸(比重 $1 \cdot 19$ ) 使用 し試料は黄血盬と共に 750 円至 $850^{\circ} \mathrm{C} て ゙ 20$ 分

2) T. G. Elliot; The Journal of the Iron \& Steel Institute 1911 No. I (412-420) 
閶燒釷し炭酸瓦斯、水素瓦斯の使用及赤熱管の使 用に就ては雨者共に實際問題として其の必要を認 めお.斯くして鋔鐵、炭素銅及 $N i-C r$ 鋼中の全 硫黄量を求め得ると述べて居る。

之に對して T.E. Rooney ${ }^{1}$ )は使用監酸は浱 厚、稀薄何れにてを完全な發生を行ひ得るも。操 作の便宜上稀㿼酸、比重 $1 \cdot 10$ )を適當であるとし. チタンウムを会をないるの及錆を生じて居ない炭 素鋼では普通發生操作のみで、硫黃の總量を得ら れるから燒鈍の必要老認めて居ない。

$\mathrm{Ni}-\mathrm{Cr}$ 鋼では或る種のるの忙普通發生操作で 完全に發生するから燒鈍の要なく、或種のもので は燒鈍により多少結果を良くするが Elliot 說の 如く完全なる定量住不可能で、斯くの如きもので は更に種え異つた溫度で燒入燒戻を行つた後、發 生させたが何等效果なく結局如何なる處理に依つ ても酸化法結果に比し著しく低值示す事を實證 した。尚赤熱管の使用は其の必要を認て居ない。

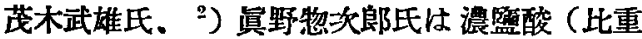

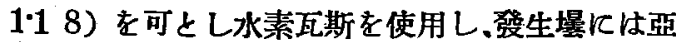
鉊アマルガムを使用した。長谷川熊彦 ${ }^{3.4}$ ) 氏外二 氏は溶解酸の浱度の影響は大きくはないが、震監 酸を優良とL。水素瓦斯或は炭酸瓦斯の通過は必 要と認め。燒鈍は特種銑鐵、特殊鋼には必要であ つて普通銑鐵、普通鋼では必要を認めす。、亞鉛ア マルガムは其の效果特筆すべきものではなく、影 響は微弱であるが、溶解困難な 試料に 数しては 幾分溶解力を增通する傾向がある、故を以て特殊 鋼に應师して居る、一般鐵鋼では 發生に當つて 硫化水素以外、硫黄化合物の箃生を認めら礼ない から、赤熱管を使用する必要のないてとを筫證 1)-4) 前揭 .
Lた。

A. Kling ${ }^{1}$ ) 及 A. Lassieur は惯監酸を使用 すべきもので、稀嘕酸では稀薄になるに從つて發 生值が低下するてとを述べを、更に標潐鋼を使用 して發生結果の修正を說した $2 、 3$ の著書を舉げ れば F.T. Sisco ${ }^{2}$ ) は使用監酸は濃厚なるを可 とし、特殊銅では著しく低值を示するのがあるか ら燒鈍を必要であるとした、然し電氣鋼、坩堝鋼 では、發生法では正しい值を得るてと不可能であ つで低值を示すから、之を補足する目的で酸化法 で定量した硫黄量既知の標潐鋼を使肞して發生結 果を補正せねばならぬと記述した。

C. M. Johuson ${ }^{3}$ )はヨード規定液の硫黄值は 標準鋼によつて決定すべきものでするとし、米國 標準局試料を推獎し且各種の標準銅を用意せよと 述べた Lord ${ }^{4}$ ) 及 Demorst 亦ョード規定液は 酸化法で定量した、硫黃量朁知の標潐鋼に滴定し て係數を求め、之によつて硫黃値を補正せねばを らぬ、而して此の蛹正は良好であるけれどる、金 屬の性質．熱處理の如何によつて發生率が各異る ものであるから、或種の鋼に滴定した規定液を異 る種類のものに使用することの不可を說いた。 其の外 Elliot ${ }^{5}$ ) 个 T. T. Morgan ${ }^{6}$ ) 字標淮 銅を使用して居る。

斯くの如く，發生法の各部分的操作に對して種 «異つた說がある。本研究では是等の部分的操作 の效果と鋼及特歼鋼に對する發生值の正否とに就

1), ${ }^{2}$ )、前揭

3) C. M. Johnson; Rapid methods for the ohemical analysis of special steels, steel-making alloys, and graphite 1909 (173-17:9)

4) Lord and Demorest; Metallurgical Analysis. $1913(89-168)$

6) J. J. Morgan; . Aids to the analysis and assay of ats; metals and fuels. 1915 (65-67) 
て探究せんとして、以下の順序で定量實驗を行つ た。

發生泆䔈驗基 1 此の項で注稀監酸のみで發生さ 灰。

(A) 分析操作:一一試料 5 瓦を發生龧儿科量

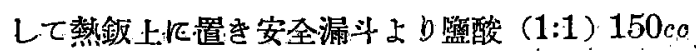
老注加し加熱して充分溶解する、此の際發生する 硫化水素瓦斯恰洽却管を經て稀監酸液 $(H C l 2 c c$ : $\mathrm{H}_{2} \mathrm{O} 100 \mathrm{cc}$ ) 50cc を入れたる洗策爆小に至り冷却 洗淮して次に醋酸亞鉛液 $50 \mathrm{c} c$ づつ大れたる 2 㑑

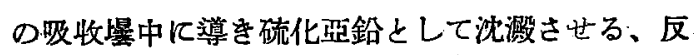
應終了すれば硫化亞鉛を含む溶液及其の他硝子管 壁に附着して居る沈溉を冷水を以て、 $1300 c c$ エル レンマイヤー・フラスコ中に洗ひ移し.之に過桃 の $N / 50$ ヨード溶液を加人澱粉を指示藥として $N / 50$ チ才硫酸ソ一ダ溶液で滴定して硫举量を算 出する。

裝置 各部分に使用のゴム製品は像め濃監酸で 處理した媵使用する。

(B) 試啝

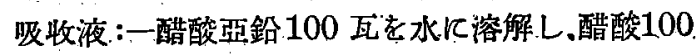
ce を加人た後蒸溜水で $1,000 c c$. とし濾過 して使用する。

規定液：一常法に上り $N / 50 \exists ー ト$ 溶液及 $N / 50$ チ才硫酸ソーダ溶液を調製し、力價の檢定 は規定亞砣酸溶液及過マンガン酸カリ溶液 …kよる。

本操作に你つて第 1 表の米國標準銅試料を定量 した結果は第· 3 表其 1 てでる。

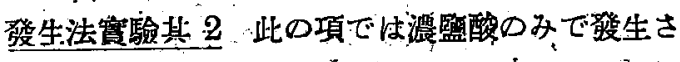
诂齐。

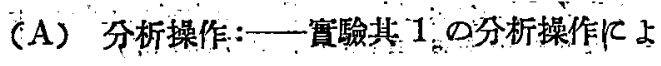

る。但し溶解酸は漂監酸比重 1118 ) 使用した。 (B) 試綝:一實驗其 1 の試樂化上る。： 本法们よる定量結果は第 3 表其 2 の如く.です 万。

登生法璂驗其 3 此の項では稀唒酸で發生せしめ 發生嚗には炭酸瓦斯を通じね。。：

(A) 分析操作：一一試料，5瓦考發生暴行程量

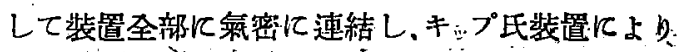
發生せしめ，過マンガン酸かり溶液(過マンガン酸 カリ. 1 瓦炭酸ソーダ 10 瓦水 $100 c a$ ）吸收液及. 硫酸 (1:10) ○各洗沙液にて洗淮した炭酸瓦斯を 5 乃至 10 分間通過して裝置內の空䀜を驅除した

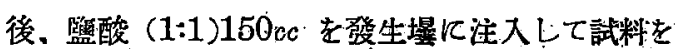
溶解士る。此の際發生した水素及硫化水素瓦斯等 は發生晴上り冷却管及酸洗涤を目的とする空暑を 經て吸收液 60scづつ入りたる 2 佔の吸收嚗に揆 り、硫化水素老硫化亞鉊友硫化カトミ゙ムとして 沈澱させる.j

此の操作中梳生嚗を適賞沉加熱して逆流を防

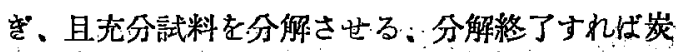
酸瓦斯を約 15 分間通じて裝置內儿㽣留する、硫 化水素を完全に驅除して吸收液に吸收させる、次 に吸收液及的他硝子管壁に附着して居る沈溜を

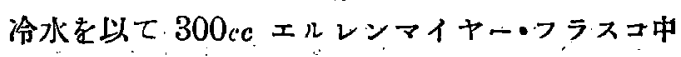
に洗ひ移し、之に過剩の $N / 50, \exists ー$ ト溶液を扣

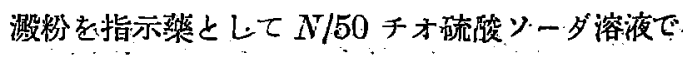
滴定して硫黃を算出する。

(B) 試器:

吸收液:一醋酸亞鉊 40 瓦及醋酸力ドミウム 10 瓦

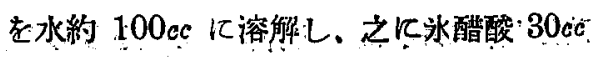

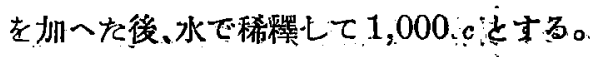

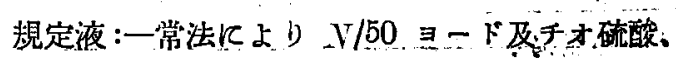


ソーダ溶液を造り、ヨード液の力價は規定

，亞䂤酸溶液を以て檢定しチオ硫酸ソーダ溶

液は規定ヨート溶液を以て检定する。

本定量結果は第 3 表其 3 亿示す通りである。

登生法實監其 4 此の項では試料を燒鈍した後、

浱監酸で破生させた。

燒鈍施行方法に就ては揫々の說があるが、本實

臨では T. G. Elliot ${ }^{1}$ )の操作に依つた、師ち同 法では燒鈍溫度は 750 乃至 $850^{\circ} \mathrm{C}$ を最も良好 とし、燒鈍にょる試料酸化防止の目的で黄血桖を 使用して居る。

(A) 分析操作:一一試料 5 瓦を科量し 0.25 瓦の黃血監を良く混合し、之を東洋湽紙 No.6 2 数で堅く包み、小磁製㘫堝に移し蓋を密閉し。

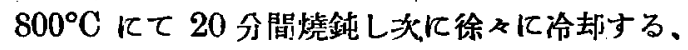
滤紙は黑く焦げ試料は塊狀になつて居る、之を碎

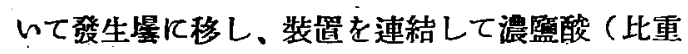
118）150cc を安奎漏斗上り注加して、硫化水素 瓦斯を發生させる，以下操作は實驗其 1 と同樣に 處理して硫黄量を算出する。

燒鈍試料では使用濾紙及黃血監几碳黄を含有す る恐むる故普通室試驗以外に二次の試驗を行ふ。 紂鐵 5 酉を探取し常法に上りて硫黃量を求め、别 に同じ純鐵 5 瓦を採り、前記の操作によつて燒鈍 を行つた後發生操作を行ひ硫黃量を求め，兩者の， 差によつてブランクを定める。

(B) 試莱:一一實驗其 1 の試樂に上る。 本法几传る定量絈果は第 3 表其 4 である。

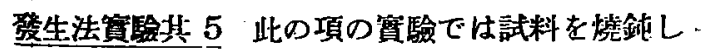
た後、稀監酸に依り發生させ、發生嚗には岸酸瓦斯 2) 证捍
を通じた、發生操作は實驗其 3 K準じて行つため であるが、只一部發生硫化水素瓦斯の洗涤を目的 と于る。茎嚗を庣して 稀監酸 ( $\mathrm{HCl} 2 c c: \mathrm{H}_{2} \mathrm{O}$ $100 c c) 50 c c$ を入ねねる瓦斯洗滌爆を連結し之は 水で泠却した。此の洗棌液は發生終了後酸化して 監化バリウムを加へをるる、硫酸バリウムの沈激 を認めす、即ち硫化水素瓦斯は此の洗淮液中に溶 解しないてとを知る。

(A) 分析操作:一一陚料 5 互を探り、實驗其 4 の燒鈍操作により燒鈍した塊妝の試料を碎いて 發生崇に移し、各裝置を連結したる後 5 乃至 10 分間過マンガン酸カリ溶液、吸收液及硫酸にて洗 涐したる炭酸瓦斯を通じ、次に稀監酸 (1:1) 150 c c を發生香に注入して試料を溶解する。此の祭 發生した、水素及硫化水素瓦斯等は發生嚗上り冷

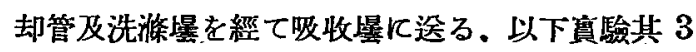
の操作さ同樣に處理して硫黄を算出す。

(B) 試染 :一一實驗其 3 の試藥による。 定量結果は第 3 表其 5 である。 發生法賽驗其 6 此の項では試料を燒針した後。

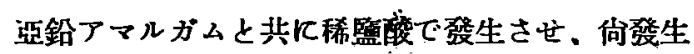
嚗には炭酸瓦斯を通じた。

發生操作は實驗其 3 に集じて行つたのである が、一部發生硫化水素瓦斯の洗㴖を目的とする。

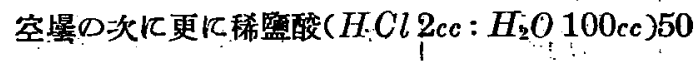
ccを入れた洗淮嚗を㙁办連絬し、次に吸收嚗を連 結し空基は水で却した。却ち本項では前項の管

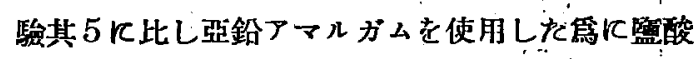

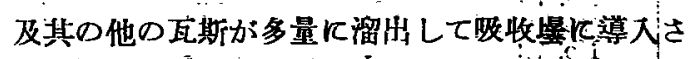

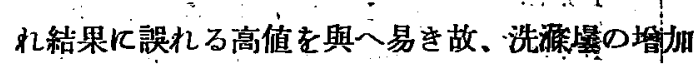
が必要であつた。發生後の洗淮液は前項向様に試 
驗したが硫黄の存在を認めなかつた。

\section{(A) 分析操作:一一試料 5 瓦を科量し，實驗} 其 4 の燒鈍操作に上り燒鈍して得を塊狀の試料を 碎いて 10 瓦の亞鉛アマルガムと共に發生樰に移 L. 各裴置を連絬して 5 乃圣 10 分間過マンカ゚ ン酸カリ溶液、吸收液及硫酸で洗滌したる炭酸瓦 斯を通じたる後、稀留焉酸 $(1: 1: 200 c c$ を墢生嚗に 注加し試料を充分に溶解する、此の際發生した水 素及硫化水素瓦斯等は發生嚗より椧却管。空嚗。 洗滌嚗を經て吸收嚗に送る、以下實匳其 3 と同様 に處理して硫黃量を算出する。

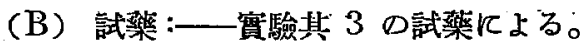
本法几依る定量結果は第 3 表其 6 亿示寸。 第 3 表の各發生法の定量值は總て酸化法の值に 比して低值であつて、第 1 表の米國標準局の發生 法硫黄平均值の如き良成績を求め得なからた、米 國標準局の平均値は如何なる操作に依つて得られ たのか其の明細を知るの機會を得さるも、本實驗
では普通行はるい發生法の種そなる場合を考虑し て其 1 より其 6 迄の發生法を施行した办，總て 低分析值を得るに過を゙かつた、後の項に記述す

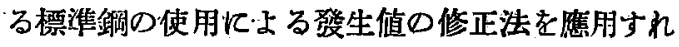
ば乘に角、普通發生法操作では正確なる值を得る ことは困難である。

實摳值は總て低きを以て、第3表では先に゙酸化 法實驗做と良く一致した、米國標準局酸化法硫黄 本均值を真の硫黃量と假定して之に對する各發生 率を算出して附記した。

發生率は最低 $19 \%$ 最高 $89 \%$ として稀監酸の みに上る發生值（其 1) 上濃監酸のみに作る發生 值（其 2) とでは鋼種により發生率に稍差違のあ るものあり、濃鹽酸を有利と認められる、C $r-W-$ $V$ 鋼等もあるが全體を通じて優劣を認め難く酸化 法に比し著しく低值である。

稀監酸に依り發生し。炭酸瓦斯を通じを設生值 （其 3)も結局前二者と大登がない、試料を橈釛し

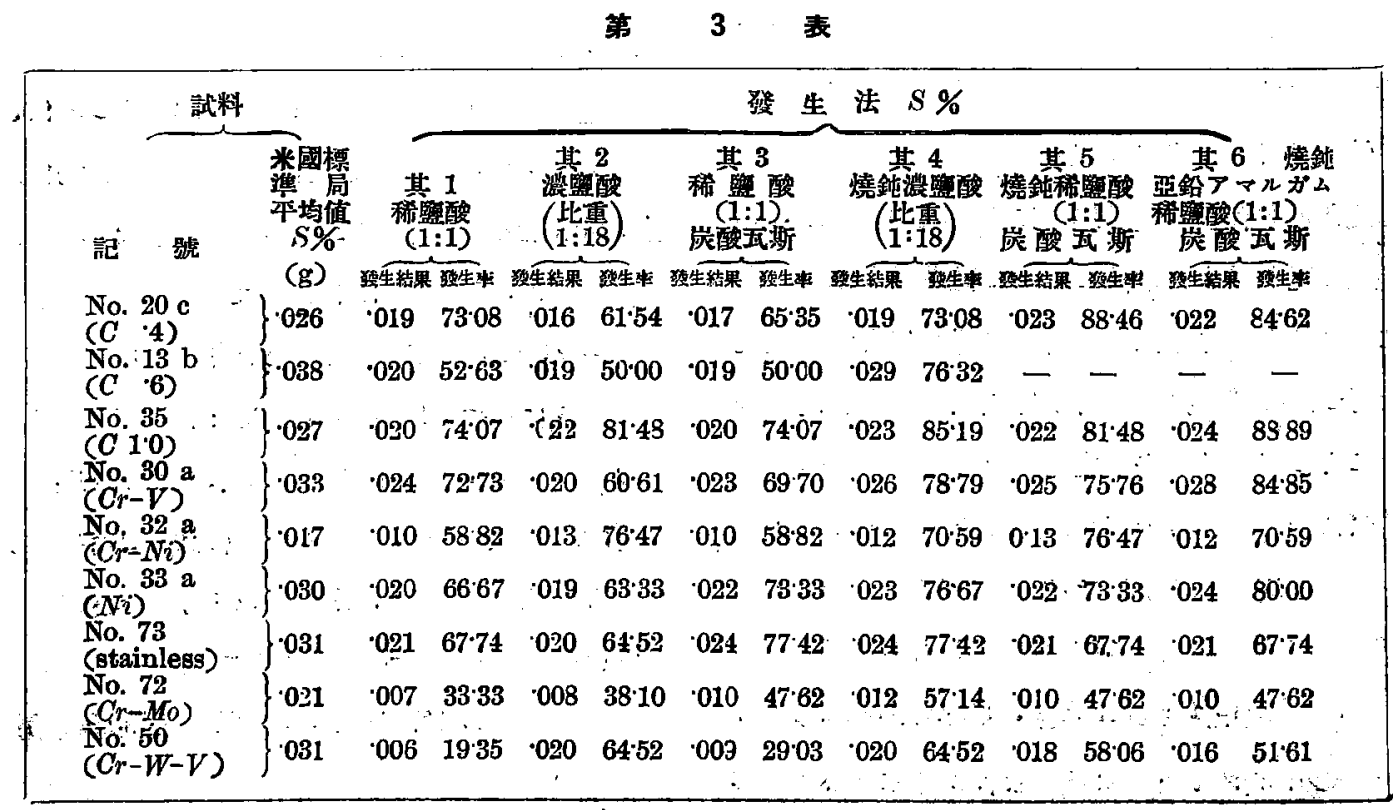




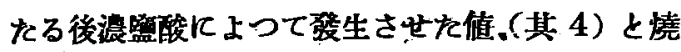
釛試料を稀監酸で發生し炭醀瓦斯を通過した場合 の值 (其 5) とは前三者飞比し相當良好なる發生 率を示してて居る、燒鈛試料を亞鉊アマルガムと共 几稀盛酸で發生させ炭酸瓦斯を通じた值（其 6) に於てる一部相當良き發生率を示するのあるも。 泉鈍試料を取扱へる前二者に比して優れて居ると も認められない、即ち以上筫驗上り發生操作に就 てて夯のてとが摆へると思ふ。

（A）酸瀑度に就ては稀監酸、浱監酸の何れ几 体りて發生させるる其の結果に大差なく、㗶生に 當つては稀監酸 (1:1) を使用する場合は操作容易 であり㛊差を生する危险も少ない。

（B）炭酸瓦斯或俚水素瓦斯の通過恃特に發生 率を良くするとは思はれないが、立前として發生 裝置內儿硫化水素瓦斯の殘溜与る可能性恃否定出 隶をんのであるから，岑酸瓦斯或は水素の使用を 還當と認む。

（C）燒鈍は發生值を良くする。抄くと.も發生 法で定量を行はんとする場合は燒鈍したる試料て 供るべるのと思考する。

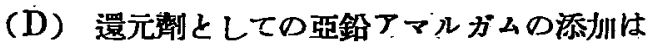
全䯏を通して特火其の效果の認むべきるのなき ๖。次の項の發生嚗中䇅溜物の處理で發生值とし て現れない，硫黄の大部か墢生龧中下殘溜して屈 る事赛より推して單に監酸のみでは還元發生の不 完全なるてとは明膫であつて、斯く未完の操作で ある以上赻くをも還元發生多多でる補助し得と 考へた探作は之を探用するを至當と考入る。

（E）硫化水素以外の硫黃化合物の分解老目的 とする赤熱管隹就ては發生操作に當うて硫化水素
以外の硫黃を含む瓦斯の發生の認め難いことは塊

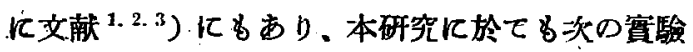
結果上り同僐推定される、故任實際問題としてる 赤熱管は必要なをものと思惟す。

次々發生狀態を銅重别上り見ると炭素銅 $(C 0.4$ 乃至 10\%）は比较的登生率良好であつて $C r-V$

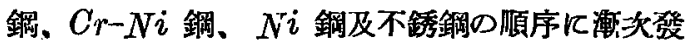
生率低下L $C r-M o$ 鋼及 $C r-H-V$ 銅化至つて 任著しく低値である。

發生法寞驗其 7 『發生嚗中殘溜硫黄の测定』墢 生法實驗で其 1 乃至其 6 の定量值は酸化法の值 に比して過小なりしを以て發生值に現忆ない。

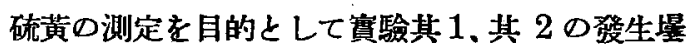
中不溶解殘查及溶液の處理を行つた。

（A）發生法實驗其 1 の發生嚗中殘溜物を濾別 して、滤液は硝酸で酸化し監化カリを加へて点弦

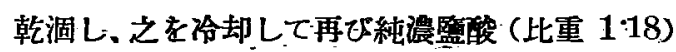
$30 c c$ K溶解し、次に徐飞に蒸發して・11 乃至 13

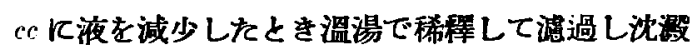
物を分離し次に $30 \%$ 監化バリウム溶液 $10 c c$ を 加一全液量を約 $500 c c$ と擋䢁後約 1 時間加溫 して充分硫酸 パリウムを沈溜させ、 12 時間以上:

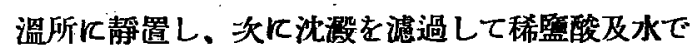
洗探し燒いて秤量し硫黄量を算出した。

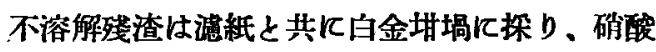
ソーダ飽和液で閏した後淈紙を燒さ、ソーダ灰及 硙酸ソーダ(10:1)の合峦で溶融し、之を篮酸及水 ，で處理して蒸發乾涸して再び純監酸几溶解し、以 下前記の淒液の處理火準して硫黄量を求めた、各 测定結果及總量は第 4 表《示す。

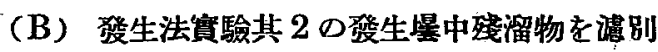
1,--3) 前挶 


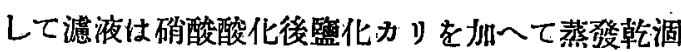
L以下 2. 酸化法實驗其 1 の操作飞依り硫黄量 を測定した。

不溶解殘渣は硝酸及監酸 ( $3: 1)$ 几溶解し、瑔的 監化カリ起加へ置き蒸發乾涸して以下 2 . 酸化法 䁈驗其 1 の操作に依り硫黃量を測定した。 各測定結果及其の總量第 5 表の如し。

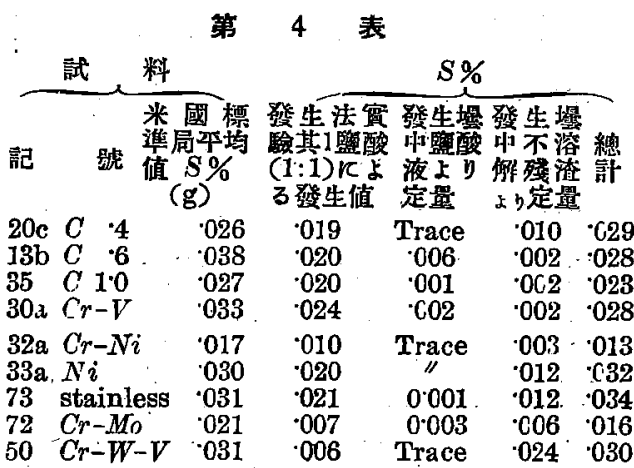

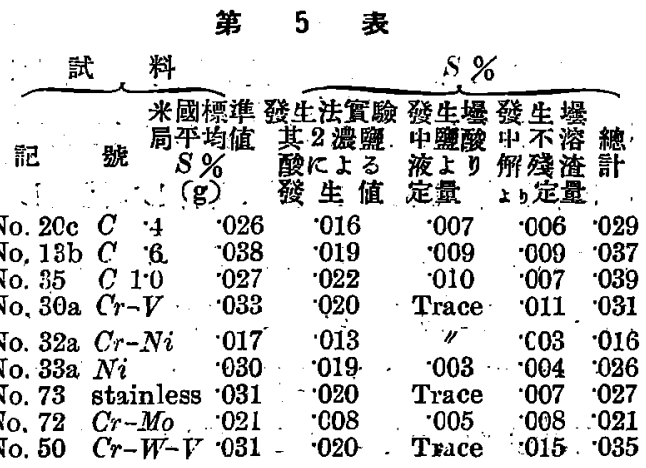

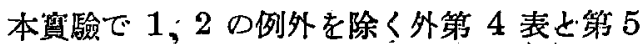

表とに於ける各發生倠と殘留硫鱼量との總計量は 大體に於て酸化法實驗結果及米國標準局平均値飞 近似の值を示す，而して此の項では微量の殘留硫

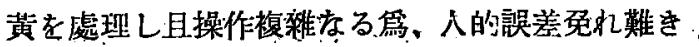
老以て特机（A）（B）の各定量法体異れる操作飞 㨜つた。

此の兩定量値よりして普通發生法絬果として現 はれる硫黃量は鋼中合有硫黄量の一部梧過ぎさる

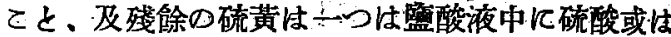
監酸に還元されない形態として殘り、一つ忙監酸 に低り還元溶解伓能の硫黄化合物として不溶解殘

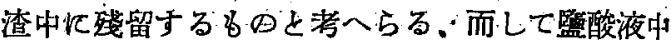

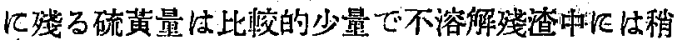
タ多量に存在し、浱監酸で處理したものは唏監酸 で處理したものに比し溶解酸中に稍に多く硫黄の 殘留するを認める。

\section{4. 低炭素鋼に就て酸化法と墢生法との 比較䁈驗}

前項米國標淮局試料では炭素量低きの选得ら れざりし定以て本項では 4 個の低炭素觟を探り酸 化、發生雨法の比较定量を行つた。鋼の分析成分 は第 6 表の如くである。

\begin{tabular}{|c|c|c|c|c|c|c|}
\hline 銅種 & 記號 & $C$ & $S i$ & $M n$ & $P$ & $C u$ \\
\hline 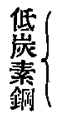 & $\begin{array}{l}10 \\
11 \\
12 \\
13\end{array}$ & $\begin{array}{l}\cdot 10 \\
\cdot 15 \\
\cdot 22 \\
\cdot 18\end{array}$ & $\begin{array}{l}06 \\
\cdot 12 \\
\cdot 01 \\
\cdot 01\end{array}$ & $\begin{array}{l}03 \\
-25 \\
\cdot 46 \\
44\end{array}$ & $\begin{array}{l}.006 \\
006 \\
.025 \\
.019\end{array}$ & $\begin{array}{r}25 \\
-14 \\
-20 \\
\cdot 19\end{array}$ \\
\hline
\end{tabular}

是等の試料を酸化法では 2. 酸化法實驗其 10 操作により、發生法では(A) は試料を燒銶し、亞 鉛アマルガムと共に發生させた、3. 發生法實驗其 6 操作に上b(B) 㤬燒鈍を行はず。直ちに亞 鉛アマルガムと共に發生させ以下 3. 墢生法實驗 其 6 に上り硫贯を定量した、各定量値は第 7 表に 示す。

試料記螘

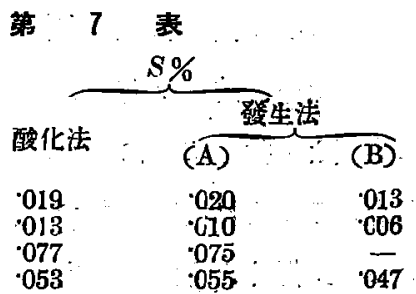

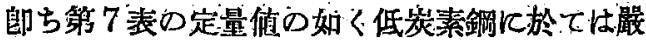
密孝当操作 $(A)$ に上り發生させた硫黄量は酸化法

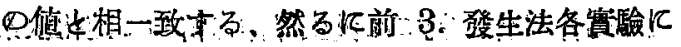


於ける如く炭素含有量の獒加したるもの。或は特 殊元素の混入したるるの等で壮如何なる操作を行 ま8完全なる發生困蘸となり、發生值は低下する。 而して是等の炭素或は特殊元秦の許容量が明白な らさるを以て發生法は一般低㞸素鋼に對し正確な る值を得られると斷言は出棵店い。

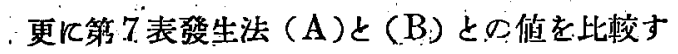
るとき燒釷が發生法の值を良くするてとを知る。

\section{5. 吳製鋼部製各種銅に就て酸化法と發生法との}

比較實驗 本項では製鋼部製各種鋼に就き酸化法 及發生法にょり定量したる結果を比校した、目的 は一つは發生法に於て各㣫の異れる成分の鎆に對 する發生率の變化を見、一つは發生に影響を及性 寸元素の概要を知るとある。

酸化法忙 2. 酸化法實驗其 1 亿據り發生法岋

3. 發生法實䟹其 1 亿據つた。

各．定量値は第 8 表乃至第 20 表に示す。 各表には試料の主要成分及酸化值に對する發生 法値の發生率を附記した。

第 8 表乃至第 20 表に於て發生法は單に稀監 酸 (1:1)のみに依るるのなるを以て燒鈍後亞鉛 アマルガムと其に處理する操作に比しては全體を 通して稍ふ低值を示すことは第3表に上り容易に 考へらるらも、其の發生师態及含有元素の影響を 知るに忙充分であると思ふ。

第 8 表炭素鋼では比較的墢生率良好であり：炭 素量の增㧈に從ひ發生率低下の傾向が認められ 当。第 9 表、第 10 表及第 11 表の低 $N i-C r$ 銅 では稍々發生率低下を示し、Ni 量稍々多をむの が(第10 表、第11表)發生率僅少ながら低下の

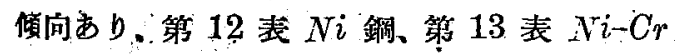

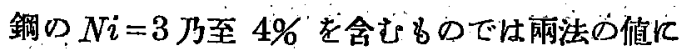

相當差違を生じ共に $50 \%$ 以下の發生率を示して 居る。

第 14 表及第 15 表の不銹鋼では $\mathrm{Ni}, \mathrm{Cr}$ 共 に發生を妨ぐるもの如く著しく發生率少なく。 第 16 表 $\mathrm{Ni}-\mathrm{Cr}-\mathrm{MO}$ 銅儿於ては發生率僅加に

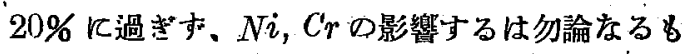
主として $M o$ が發生率を俧くすると洘へらる。 第 17 表牛高速度銅 (1)では $C ， W$ 等が發生 を妨ぐるものですら5。第 18 表牛高速度鋼 (2) では主として Mo，Wが大部分硫黄の發生を妨 げるるのと思はれる。

第 19 表及第 20 表の高速度鋼”1)(2)では發 生值著しく低下し大部分の硫黃は發生值として現 はれない、斯くの如く罚しく影響を及将す元素と しては $C r ， W$ 及 $V$ 等をるへく、第3表 No. $30 \mathrm{a} C r-V$ 銅、No. $32 \mathrm{a} C r-N i$ 鋼の發生值よb 推して $\mathrm{Cr}, V$ の影響は左鲧大なりとは侾へられ ず、主として約 $20 \%$ を占むる，Wが硫黄の發生 を妨ぐるものと思惟せらる。

節ち發生法で硫化水素瓦斯の發生を妨げ其の值 惡する元素に就ては前述の米國標準試料に對す る發生法實驗結果第 3 表に於ける場合とよぐー畋 して居る。

主なる元素は，Mo，W 皮 $N i: て ゙ M o ， W$ では 少量を合有するも著しく影響し $N i$ は其の含有量 に逆比例して發生率の低下を認めらる。 $C r, C$ も 其の含有量多をるでは發生率を惡くする。鋼中 で是等の諸元素上硫黃との間に複雜なる化合物を 構成し監酸により硫化水素瓦斯として發生し難き

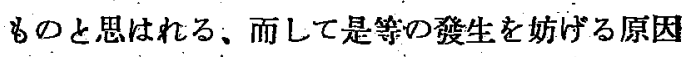

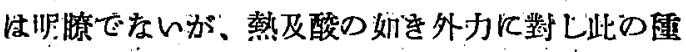




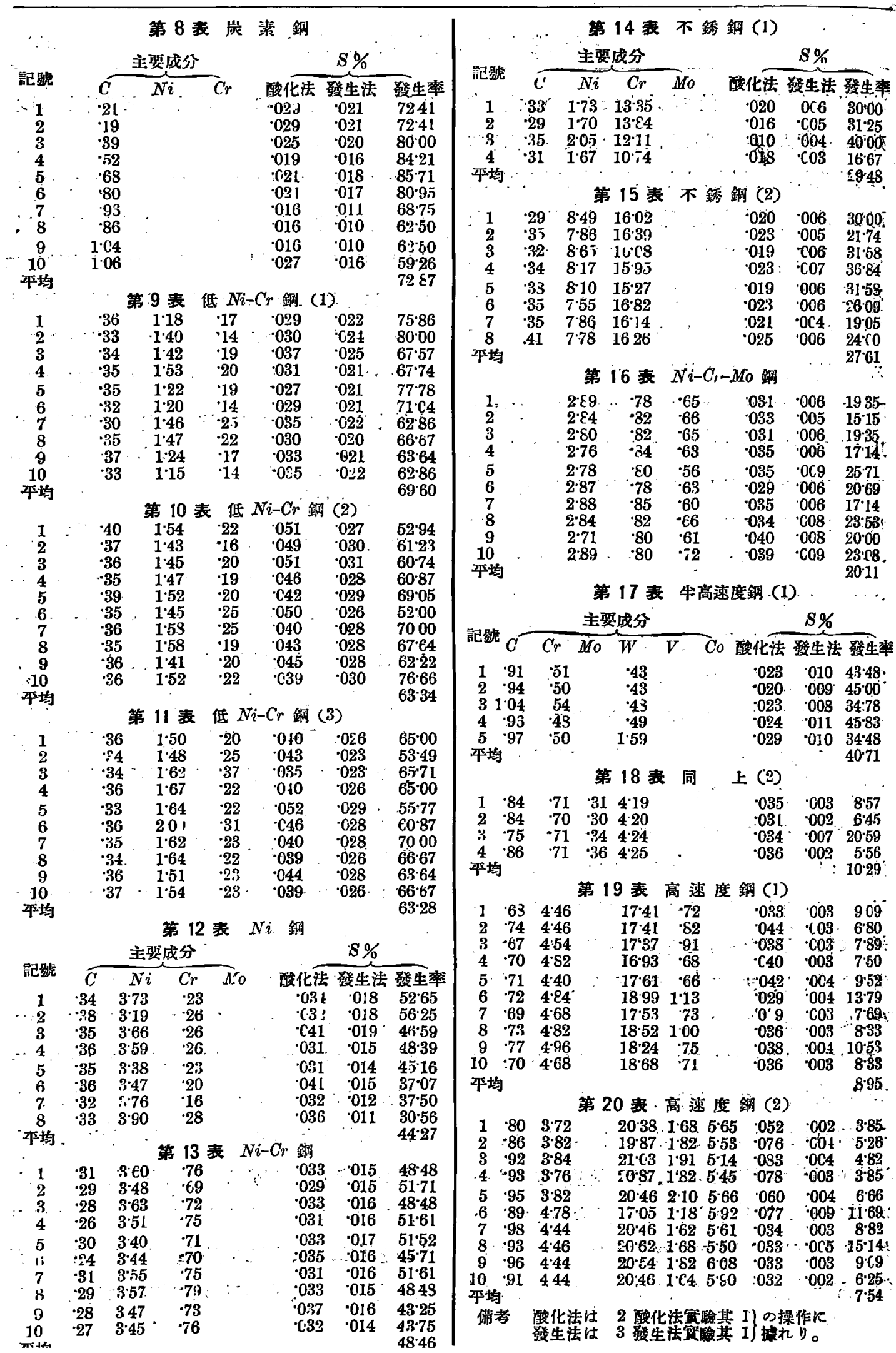


元素加硫黄者安定化せしむる事は否定し得ない。

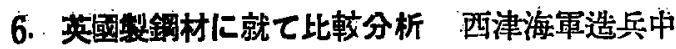
位英國に監督官として堲在せられれ當時、硫黄分 析比较の葛、或、波社、毘社、トーマス・ファー 又社及妿社の各社で硫仝を定量した $\mathrm{Ni}-\mathrm{C} r-\mathrm{Mo}$ 銅の分析試料の殘部を造附せられをるのを製鋼部 で定量を行つたもすを記載する。

製鋼部酸化法は 2 . 酸化法實驗其 1 、發生法は

3.. 發生法䐝驗其 1 の操作に據つた。

各社製鋼の成分及硫黄比較分析結果は第 21 素 の如し。

第 21 表。

\begin{tabular}{|c|c|c|c|c|c|c|c|c|c|c|}
\hline & \multicolumn{4}{|c|}{ 成 } & 分。 & & & 7 & \multicolumn{2}{|c|}{$S \%$} \\
\hline 楮 & $C$ & $\boldsymbol{S}_{i}$ & $M n$ & $P$ & $N i$ & $C r$ & Mfo & 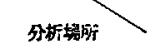 & 酸化活 & 發生法 \\
\hline 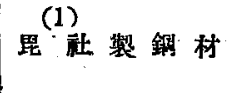 & 35 & $\cdot 287$ & -40 & $0 \leq 8$ & $3 \cdot 49$ & 69 & -26 & 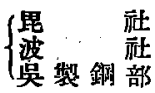 & $\begin{array}{l}.026 \\
\cdot 024 \\
\cdot \mathrm{C} 26\end{array}$ & $\begin{array}{l}-\bar{c} \\
\cdot \overline{123} \\
019\end{array}$ \\
\hline 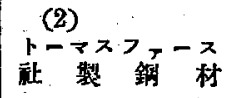 & $\cdot 29$ & $\because 5$ & 63 & .024 & 3.07 & 61 & 55 & 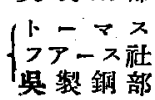 & $\begin{array}{l}.024 \\
.026\end{array}$ & $\overline{0}$ \\
\hline - 3 安秲製 $\{\mathrm{E} 6$ & $\cdot 29$ & $\cdot 10$ & $\cdot 63$ & 018 & $2 \cdot 38$ & .54 & $\cdot 50$ & $\{$ 案:製銅部 & $\begin{array}{l}.039 \\
.030\end{array}$ & - \\
\hline${ }^{\prime}{ }^{\prime}$ & .27 & $\cdot 17$ & $\cdot 59$ & 010 & 236 & $\cdot 54$ & 53 & $\left\{\begin{array}{l}\text { 案銅製部 } \\
\text { 部 }\end{array}\right.$ & $\begin{array}{l}0.30 \\
.027\end{array}$ & - \\
\hline
\end{tabular}

ある。3. 發生法實驗上り考察して實驗其 4 乃至 其 6 の操作に依る場合は更に良き發生を得られ るもの上考人られるも、試料僅少にして充分なる 發生法の㝠驗を行ひ得さりしを遺憾とする、只茹 に注目すべは昆社及製鋼部酸化法值 $0.026 \%$ に 對して製銅部發生值 $0: 019 \%$ 几て登生率 73.08 \%となる。之と大體近似の成分を有する前記の 5 製鋼部製鋼の $\mathrm{Ni}-\mathrm{C} i-\mathrm{Mo}$ 銅の發生率 $20^{*} 11 \%$ (第 16 表參照)と比較するとき著しき差違を認め らる、同梂にトーマス・ファース社製鋼の酸化法值 0.026\% 亿對して㡎生法值 0.014\%で發生率 53 . 85\% となり、前二者と夫ょ異れる發生率を示し て居る。 是等上 3. 發性法 第. 3 表 $C r-M o$ 銓 ○各發生結果と，を 剠照するとき、化學 成分より考察し得る 發生率と賽際の發生 率上は全く正反對で ある.即ち發生率の

第 21 表の結果より次のてとを云ひ得ると思ふ。 英國各社の酸化法操作壮明膫でないが、必ずしも 總て同一操作とは考へられす。然る几其の定量做 はよく一政して居る。師ち酸化法では異る場所。 と提作にて定量するも常に正碓な値を求め得る。 次波社の發生值.0.023\% は同䄈定量の酸化 “法值 $00024 \%$ と一致して居る。之は Elliot ${ }^{1}$ )法 に较つたるのでするが、之に對して製鋼部では俙

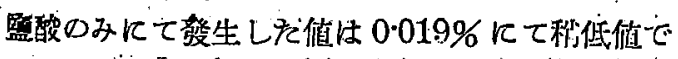

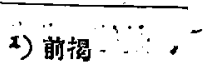

督化は單に化學成分による許りでなく，其の鋼の 脫酸狀態等の如何に著しくを右せられることは明 白である、電氣蠦鋼と平曥鋼とでは成分同一でる 可溶性を異にする）此の點に對して分析試料の燒 鈷か請ぜられたが、其の效果に就ては既述の如く

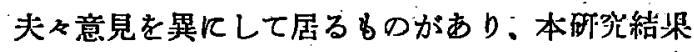
では燒針の效果は認められるも：来だ正碓な分析 值を得られざるは勿論、一定した弦生值を得るこ とる不可能である。

\section{7. 標準鍊使用による發生法結果の候正に就て 弦} 生法では一部の例外を除く外、一般に完全店る墢 
生不可能ですり常に低值を示す、此の缺點を除き

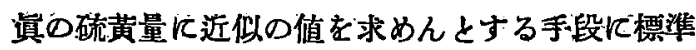
鎆它使用飞依る絬果 ${ }^{1-5}$;修正法がある。其の月

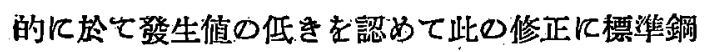
を使用した場合: 6-8) 標準溶液か力價の檢定を便 にする䉆に標準鋼を使用したるのと想像される場

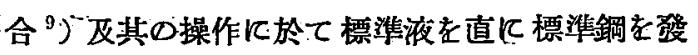

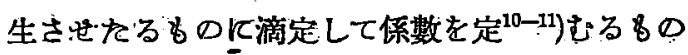
と、嚴密に規定液字調製したる後更に標準鋼を發 生させをるのに滴定して硫黃值の保數を求むるも の等の差違がある、然し要するに是等は總て酸化 法で定量した硫黄量既知の鋼を標準鋼とし、之を 常法几传り發生操作を施行し滴定して發生硫黄值 它求めて係數を算出する。

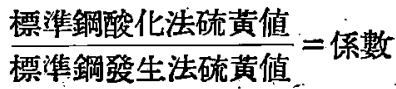

此の係數を同じ武祡及規定液を用ひ、同様なる 操作によつて得を未知試料つ發生值に乘じ:其の 試料硫黄量とするのである。

而して或は各種凹標準鋼を用意せよと謂ひ ${ }^{12}$ ) 或は金屬の性質に因り硫化水素の發生率は異るを 以て一つの係數を其の標準鋼と異る性質の鋼に應 用するの不可なるを說いを。 ${ }^{13}$ ).

，以上の標潐銅による修正法を本實驗上り考察す s.r.

(A) 單にヨード標準液の調製の便上り標蕉銅 に滴定するを目的とする場合. 本實驗では低炭素 鋼Ф一部以外は總て發生法任低值を示した。故に 其の標準鋼の選定が當を得なければ正しきヨート 標潐液の力價を求むるてとは不可能となる、若し 假に發生率 100\%の炭素鋼を標售鋼とする当。之

(1) - 23) 前揭
によつてカ價を定めたョード標淮液よりも嚴密に 調䌘した規定液が分析值の正碓度と云ふ點上り考 へて適當なること明白である。

(B) 张生法の低值なるを認めて之を修正主る

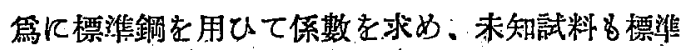
鋼と同樣な率で發生するとの假定の詐に此の係數 を未知試料の發生值に乘して。買の硫黄量に近似 の值を得やうとする修正法に就ては、本研究で明 かなる如く、鋼の化學成分の如何及其の組織の如 何に因つて各其の發生率を䱮にするるのである以 上.一般硫兴分㭛に於て一:三の代表的標淮龬学 得ることは不可能であり：若し或る種の鋼を探用 し標蕉鋼としで一般分析に應用した場合、其口龬 と發生率の同樣な者にのみ比较的正しき結果を與 人、他は總て䛊れる結果を興ふるは論を俟たない。 故に各種の標準銓を必要とするものであるが。 單に近似の化學成分の標集鋼を使用する程度では 既述の如く其の合硫狀態の如何に因つて注發生率 反著しき差遠を生するを以て適當でない。鋼の性 質に應してそれと同じ發生率を有する標集銅を探

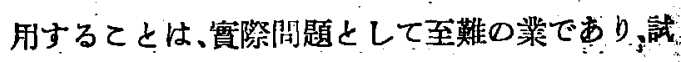
料に應じて各種の標潗鋼を自由に得らる〉場合と 踓勺各標潐鋼を酸化法で定量する煩雜を宒れ難を” を以て：一般硫黃分析法に本修正法を探用するて よは不榶當でする。

只例外と乙て試料が標集鋼と同樣な設生率を有 する場合のみ正確に近い値を得られるのであるか

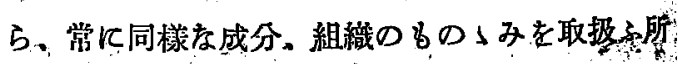

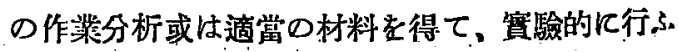
場合は此の修正法を適用するととが可能であり、

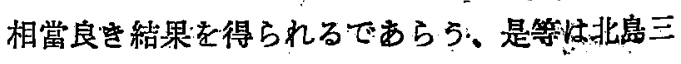




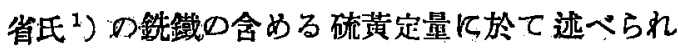
た處と一致するものであるが、前述の理由によつ

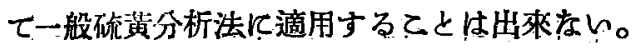

結局發生法では現在行はれて居る各種の處理法

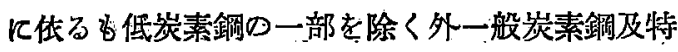
殊銅に對しては常に低分析檤を示士。

\section{第II章 銑鐵の硫黄定量に就て}

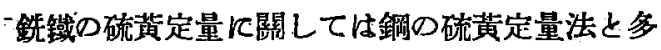
少趣を異にした點があすたから章を分つて記述し

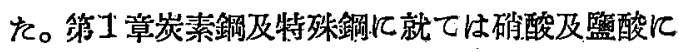
よる酸化法で正稚な値を得られ、發生法では種ね の方法を講晾るも常に低分析值を示した。銑鐵に 於ても同様儿發生法では正しい值を得難いのでは

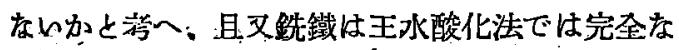
る硫黄量を求め難いと說いた例为市つたから、其 の正否を碓め一般銑鐵の硫黄定量に用ひて、常に 正確古值を示す分析方法を探究した。鉄鐵に對す る既往文献飞就ては、緒言及第 1 章 3 、發生法 の項に述へた如く、發生法にて正確学分析檤を得 られるとなするの、或は酸處理による酸化法にて

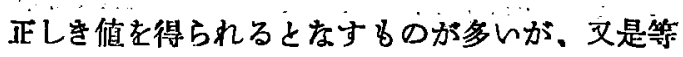
の操作にては涩足な分析值得難く、其の他の定 量方法を選ぶべきであると謂ふるのもある。是等

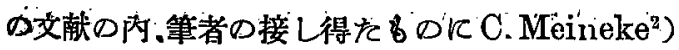

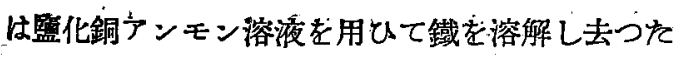
殘留物を酸化溶解した。

H. K. Bamber ${ }^{3}$ ).忙硝酸で溶解し蒸發乾涸し た後ンーダ灰で處理し鐵を分離して硫酸バリウム

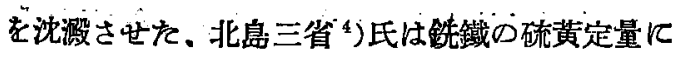

1)、勿前㷎

$\left.{ }^{2}\right)$ C. Meineke; The Journal of the Iron-\& Steel Institute. 1885 No. II (333)

(3). K. Kamber $\%$.

1894. No: I (819-327)
當つて單に酸のみに依る處理で岋完全ならすと し、臭素酸化法バンバー法、マイネ弓法を探り操作 を改善した、K、K: Jarvinen ${ }^{3}$ つは鐵を臭素水 で酸化溶解し之に監化バリウムを玑一濾過して賎， 渣をソーダ灰と硝酸カリさで熔蠤した。

A. A. Blair, 2) Fred Ibbotson, 3) F. T. Sisco ${ }^{4}$ )は各其の著書に銑鐵を王水酸化法で處理 した場合は一部硫黃が畾鉛珪酸の泌澱中に殘溜士 るを以て、是等の黑鉛理酸の殘柦を熔融酸化して 之より硫蕒を定量して主液より得を硫黃量に州算 すべしと記述して居る。

尚 A. A. Blair ${ }^{5}$ ) は斯かる铁鐵の全硫黄を求 むる方法としてバンバー法を推獎した。

斯くの如く銑鐵では硝酸酸化法、王水酸化法に 種々異諭がある、故に本章に於ては發生法、硝酸

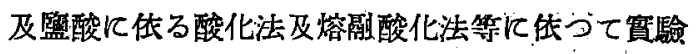
を行つた。

1. 試料及其の他 2 項以下 5 項の各實驗には米 國䄽蕉局䅺集試料鐵 No. 7a（米國糟潐局平均俳 $S=.05 \%$ )同 $N i-C r$ 鑄鐵（米國標準局平均値 \% . $N i=1 \cdot 0 . C r=0.242, S=0.033$ ）、本溪湖，純 1 號 (1)、(2)、嶥典 A. J \& C. 同 Bofors; 及製造所 不明の純銑鐵 1 號(1)，(2)の8 種を用し、6 項 飞注典 $\mathrm{NH}$ 同 Herrang、同 I, 同 L.B.H， 純鋔鐵 1 號1)乃至(5)。本溪湖純 1. 號。本邦座 1 號（鞍山）。本邦虐 3 號(鞍山) 1 、2 及ベージッ ク用銑瀻の 14 䅜を使用した。

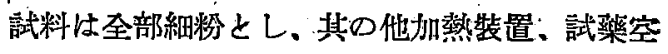
試驗等總て第 I章 1 亿述べたものと同樣である。

1)、3)、4) 前揭

2) A. A. Blair; Chemical Analysis of Iron. 1918. (55-68)

5) A. A. Blair; J. Iron \& Steel Institute. 1898 No. I. (537) 
尚銑鐵のア゙ルカリリ熔融には本研究では酒精ブンぜ シ燈と同理淪に基き䌘作した製鋼部製の酒精貲燈 を使用した。

\section{2. 各種銑鐵に就き酸化法亡發生法との比較實驗} 本項では 8 個の試料を探取して各異れる酸化法 と發生法とで實驗を行つた。

分析操作: 一一發生法 A は稀監酸のみに依り發 生させた操作は第 $I$ 章 3 發生法璸驗其 1 几ょり 發生法 B は試料を燒錐したる後、亞鉛テマルガ ムと共に發生薷に移し、稀監酸で發生させ發生嚗

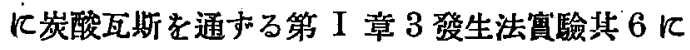
據つた。

酸化法 A は酸にて溶解酸化後黑鉛珪酸を除を 第二鐵孟液存在の許に硫酸バリウムを沈澱させ そ。第 1 章 2. 酸化法實驗其 1 亿より。

酸化法 B 它試料を溶解酸化L黑鉛珪酸分離挠 亞鉛で第二鐵臨を還元した後、硫酸バリウムを泌 澼させた、第 1 章 2. 酸化法實驗其 2 亿㨬つた。

以上各操作により定量した值は第 22 表の如く である。

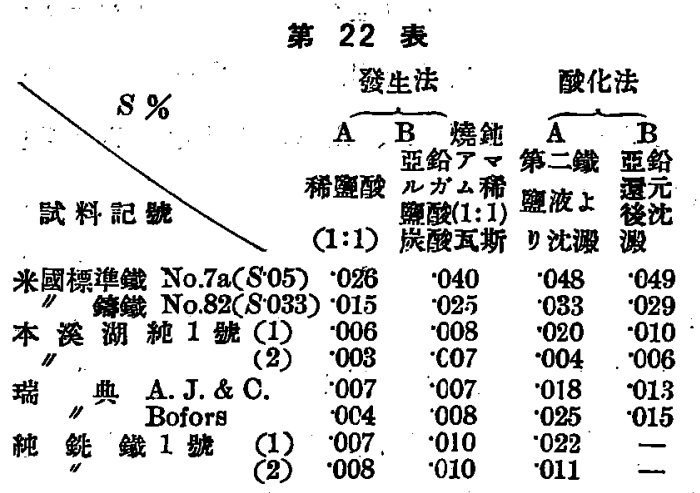

- 第 22 表の結果では發生法の燒鈍後亞鉛アマル ガム上共に發生させたるのは、單に稀價酸のみに

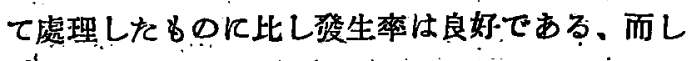
て硝梳及篮酸による酸化法す值に比しては本溪湖
純 1 號(2)、純鉄鐵 1 號 (2) を除く外恃著しく 低值である。

酸化法に於ては第二鐵監溶液より沈澱させをを のと第二鐵を亞鉛で第一鐵に還元した溶液より沈 溉させたりのとの間に差違を生じた。

鋼の定量の場合は良く一致した值を得られたる に反し:鉄鐵では雨法を繰返する。銑鐵の種頜に上 り一玫しを值を得られるものと、相當茥違を生す るものとがあつて、第 22 㤗の分析值となる。

\section{3. 發生法に於ける㜊生理中殘留硫黃の測定 2} 項の發生法の值低きを以て發生嚗中殘留物より硫 榎の定量を行つた。其の操作は、

前項發生法 B K於り万發生嚗残留液を谟別し て濾液は硝酸で酸化し、監化カリを加へて蒸發乾 涸し再び監酸に溶解し、以下第 1 章 2: 酸化法 實驗其 1 の操作と同樣にて硫黄量を求めた。

不溶解殘渣は㴔紙上共に、ニッケル朋堝に取り硝 酸ソーダ飽和溶液にて潤した後罳紙を燒き、之に 過酸化ソーダ及ソーダ灰(1:1)の合劑を加一熔融 して湯で處理して滤別し鐵老除いた後、監酸性と 七て蒸發乾涸し監酸（比重 1-18)5 $c c$ 及少量の湯 飞溶解し滤過して以下第 1 章 2、酸化法實驗其 1 の操作と同様に處理して硫黃量を求めた，各定量 結果は第 23 表發生法の項に示す。

第 23 表に上り鉄鐵を發生法にて處理した後の

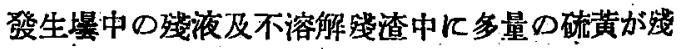
留するを知る、而して是等の琖留硫黄量と先の發 生值との總計量敋第，22 表の酸化法の值に比し、 米國標潗試料鐵灭同䥂鐵を除く外任著しく高值 示して居る。

\section{4. 酸虑理による酸化法に於て取除がれた黑鉛拄}


酸の氿没中より硫黃の測定 前項の實驗微果上り 推して、鉑鐵では硝酸及監酸に依る酸化は完全に 行はれす、黑鉛珪酸の殘渣と共に一部の硫黄が遺 襄されそのではないかと思惟される、故に此の項 では硝酸及監酸に依る酸化法で滤過分離しを黑鉛 理酸の沈筂から硫黄の定量を行つた、定量操作は

前 2，項賽驗の酸化法 A の操作中に取除いた 理酸及黑鉊の殘渣を演紙と共にニッケル朋堝に入 れ硝酸ソーダ飽和液で閏した後、滤紙を燒き之に 過酸化ソーダ及ソーダ灰(1:1)Ф合劑を加人熔融 L.以下前 3. 項發生法不溶解殘㴡の處理と同樣 亿行つて硫带量を求めた、其の實驗結果は第 23 表酸化法の項に示す如くである。

師ち第 23 表により銑鐵では硝酸及㿼酸に上る 酸化法で處理した場合、必すしも正確な值を示す るのでなく、銑鐵の種類によりては相當多量ひ硫 黄が其の操作中に取除かれる、黑餂珪酸の沈激上 其に遗率され定量値より漏んるものなるてとを知 sto

・而して定量值より漏れる硫黃量は一定の割合を 取ら才、各銑鐵の種類性質に上つて異る、酸化法 の值と殘查中の硫黃量との總計量は發生法の發生 值と各殘留物中の硫黄量との總計量と良く一致す
る點より考察して是等の總計量は各鋅鐵に含まれ る筫際の硫黄量に最す近似のものであると思は， れる。

5. ，アルカリに㳖る熔融酸化法實驗 前述各實㯺 几依り發生法では無論、硝酸及監酸による酸化法 几於ても正倠なる值を求むるてと不可能斿りしを 以て、本項では次のアルカリ熔融酸化法を施行し。 t。

分析操作:一一試料 2 瓦を二ッケル块堝に取り 10 倍の過酸化ソーダ及ソーダ灰 (1:1)の塎融柰 と混和し良く靦拌しつ」揢融酸化して之を約 100

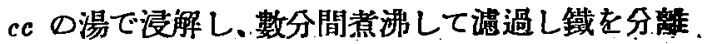
した後濃留酸（比重 $1 \cdot 18$;で中和し $10 c c$ を過剩 几加一て蒸發乾涸与る。冷却後濃監酸比重 1:18)

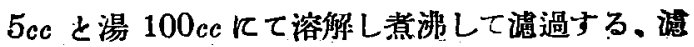
液を探り以下第 1 章 2. 酸化法賽驗其 1 の操作 及試渠により硫黃量を求める、其の定量优は第 23 表アルカリ熔融法の項に示す。

，第 23 表に於て揢融酸化法の值は，發生法の登 生值と發生嚗中殘留硫黄量との總計量及硝酸並に 監酸に依る酸化法つ定量值と其の不溶解物黑鉛珪 酸の沈澱より定量した硫黃量との總計量と一致し て居る、米國標集鐵及同鑄鐵の定量值は標準局の：

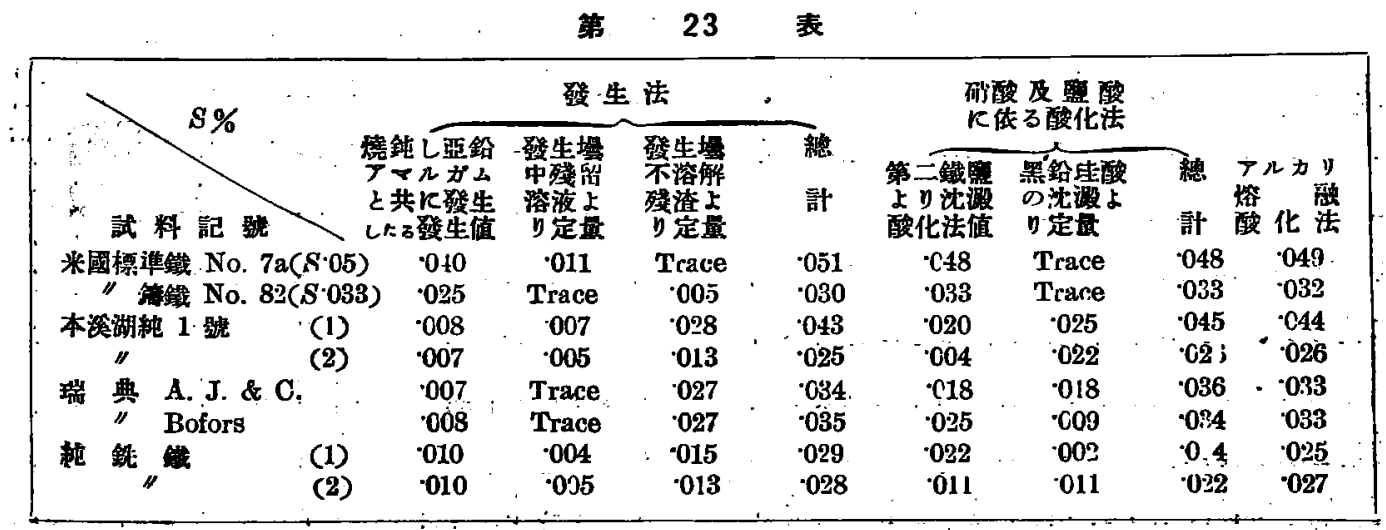


硫黄本均倠さよく一致する。郎ち本法は鉄鐵に對 して正碓なる硫黄量を求め得るるのと認めらる。 本研究に此のアルカリ熔融法を選んだ理的は 2

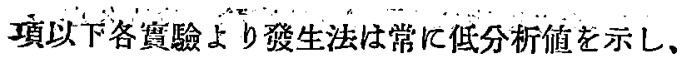
碎酸沃伐る酸化法でも大部分低分析值を示し、一

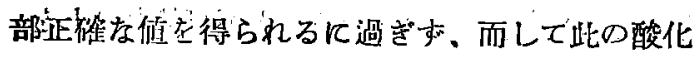

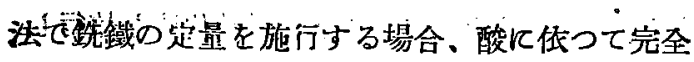
に酸化が行はれたるか否か外外覞により區別する ことば不可能である。

!的ら完全溶解酸化が行はれをと認められるに

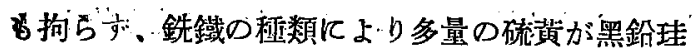
酸の沈浱中に混丈して取捨てられ。酸化法の定量 値から漏れる。故に裳に此の力法で全硫黃を求め やらとするには赻くも其の試料の如何を問はず。 黑鉛及珄酸の沈澱をアルカリで揢融酸化しとより 得をる溶液を主液と合するか、或は第 23 表の如 く主液及沛搌物を各定量した後合算するか何れか て據らねばならぬ。

斯くては操作煩雜となり定量に長時間を要し結 果にも湖を生じ易い，故に銑鐵の一般分析法とし て不適當である：そてで第 2 章卷頭に記逮した文 献のアルカリ熔融或は其の他の酸化劑に低る操作 中バンバー法。臭素酸化法等も適當であると考人 られる。然し本研究に於ては是等を参照し工業分 析的立場よりして出来得る限り定量時間の短縮。 操作の比較的單純なるとと、結果の正確なること 桪を條件として熔融酸化法を行つた。

師ち本操作に位る場合は銑鐵中の硫黃の形態如

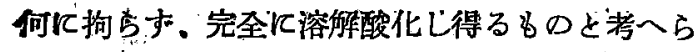
れ、而して其の竇驗結果的前述の如く正確なる全 硫黄量を求め得た。

倘本操作では沈溊生成に當り硫酸嘕を使用する
ことにしたが、本項の筫驗では硫酸監を使用した 場合と使用しない場合とに就て定量し其の結果に

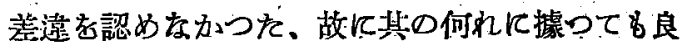
レが、只硫酸監の使用は操作を容易となす便利が ある。

6. 銑鐵の硫黃定量實驗補遺：各實驗でアルガリ． 飞依る熔融酸化法の分标値の常飞正確なるは朋白 となれるる。之に對して㗂酸及醖酸による酸化法：

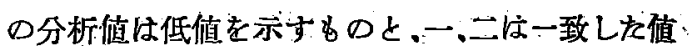
を示するのとすり、酸化法の值の低下する割合は 一定でなく銑鐵の種類により異つて居る。

勿論明かではないが、發生法で發生茶凹少きる

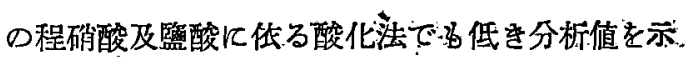
寸如く考人万方。

・新沉 14 稞の試料を探取し發生法：酸處理によ る酸化法及揢融酸化法で定量しだ。

分析力法:-一發生法は燒鈍試料を: 亞鉛ア、ル ガム上共に稀監酸で發生し發生悬に炭酸瓦斯を通 じた第 I 章 3 發生法賽驗其 6 に據つた。

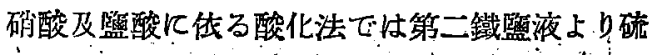
酸バリウムを沈洎させた、第Ｉ章 2 酸化法實羷 其 1 により。

熔融法は前項過酸化ソーダ及ソーダ灰 (1:1)の

\begin{tabular}{|c|c|c|c|}
\hline 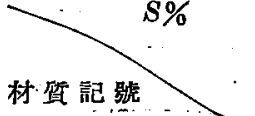 & 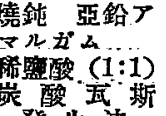 & 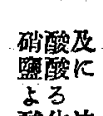 & $\begin{array}{l}3 \neq y \\
k \Sigma\end{array}$ \\
\hline $\begin{array}{l}\text { 典 }{ }_{\text {HER }} \\
\text { HeRA }\end{array}$ & 007 & 007 & .018 \\
\hline I & .011 & & .019 \\
\hline " I. B. H & .029 & .055 & 066 \\
\hline 銭: 钱 1 號 (1) & 012 & 015 & 019 \\
\hline (2) & .008 & 017 & .627 \\
\hline$(4)$ & 0.015 & 018 & 036 \\
\hline & & & \\
\hline 溪潮 & .007 & -018 & 038 \\
\hline 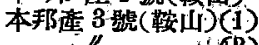 & .056 & & $\because 08$ \\
\hline 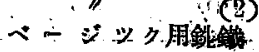 & $\begin{array}{l}053 \\
037\end{array}$ & $\begin{array}{l}.066 \\
.057\end{array}$ & $\begin{array}{l}.079 \\
.058\end{array}$ \\
\hline
\end{tabular}




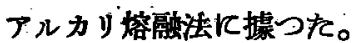

“客定量値は第 24 表である。

一即古第 24 表の各定量值儿於て方能記各實驗結

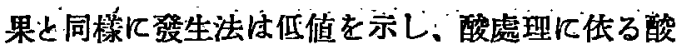
化法では大部分低值なるも僅に一部炇熔融法結果 と一致する8の、或は稍々近俱の值を示するのが ある。而して其の定量值の低下の割合恃䤶鐵の種 類により異つて居る、即ち發生率の少なきもの程 酸處理几传る酸化法の定量㨁低下寸る傾向を認 ら得る。

管て (lymer ${ }^{1}$ ) 及 F. H. Williams ${ }^{2}$ ) 住硝 酸及酮酸に依る酸化法で、數人口化學者により定 量された同一種の鉄鐵の硫黄量に著しく崖違のあ つたものにつき斯くの如き大なる誤差の生和る原 因として黑鉛珪酸除去の䉆に行子蒸發乾涸の際に 其の處理法適當ならすして、監基性鐵監を生じて 結果を低くするか、硫酸パリウム沈澱生成に當り 酸濃度適當ならすして結果に高低を招來するか。 であると述べた。

“本研究认於て子第 22 表酸化法結果の第二鐵監 楁液から泷澱させたものと第二鐵を第一鐵に還元 した溶液から沈漫させたるのとは相當差違を生し た、然し是等の差違は前記の様を理的によるるの をは思し難し、第 1 章第 2 表に於ける炭素鋼及 特殊鋼では。第二鐵監溶液より沈搌させたるのと。 第二鐵を還元した溶液上り沈浔させをものとは共 に二政して扂り、且正確を值を示して居る。

溶解酸化後に於ける操作でば鋼の場合除鐵の 場合す同梯であつて、單に蒸發乾涸の處理方法或 は泍没生成に於ける酸漂度等によつて銑鐵のみに

1) Oymer; The Journal of the Fron \&-Steel Institute 1893 No. I (4C8)

2).F. H. Williams;
誤美を生する筈はない，然るに事實は是等の雨力 法の值が一政しないのみならすアルカリ塔融法に 毛る定量値に比し遥儿低値を示すものが多く、其 の割合も夫ネ異つて居るのであるから、其の原因 学他に求めねばをらぬ。

鋎鐵を發生法で處理 した場合.．監酸に不溶解性 硫黃の存在するてと注第 24 表で明白であり，之 は鉄鐵中 ${ }^{1-3}$ ) 凡合まれる硫黃と他元素との結合の 狀態如何に左右されると說いて居る;

硝酸及監酸に侤る酸化法でも銛鐵の䅅類により 操作中に取除く哭鉛珪酸の沈搌中に碳黃名混入し て定量値より漏れて居ることは第 23 表の如くた。 あり。且發生率の少いるの程酸化法の定量値多低 くなる傾向等上り推して發生法に於ける場合と同

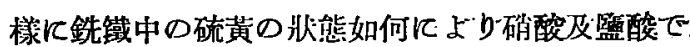
處理するも充分な酸化が行はれ慕いのでるいかと 想像される。

從つて第 22 表の酸化法結果が其の處理法の如 何により差異を生和るのは發生法で其の處理法異 れば發生值の變化を生方゙る如く硝酸及監酸の量或 は補助峦の異るに從ひ酸化の程度を多少異にする 雼であらふ、刎論硝酸及孟酸を使用し得る點に於 て其の酸化能力は發生法の監酸の還元能力に比 て遥に大なるは其の定量値により明白である。

更に第 23 表に於て米國標準鐵及同鑄㖪の酸化 法の結果がアルカリ熔融法の結果とよく一票する は、是等の標集試料九既に再溶解により造られた

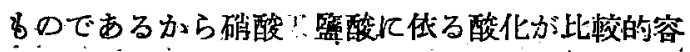
易に行はれたるのと考へらる。:

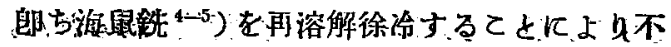

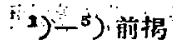


溶解性硫黄は減少し發生率良好となるべしと述べ られた、是等は又單に發生法に就てのみ謂はるぺ きものでなく、硝酸及監酸による酸化法の場合に、 於ても適應し得るのではないかと思はれる。

結局發生法で硫化水素瓦斯の發生を妨げ、硝酸 及䣿酸に依る酸化法で、酸の溶解酸化を妨げ、全硫 黃量を求むるととの出來婂因は鐵中で炭素、珪 素、硫黄等の間に構成される複雜な不溶解性化合 物の影響に低るものと想像される。

而して第I章鋼の墢生處理の場合に生す和不溶 解性硫黄は容易に确酸及監酸に依り分解せられた るに反し、銑鐵では硝酸及監酸に依るも分解され 難い點より見て、鐵中炭素、珪素等の間に生する 硫黃化合物はより一首酸に對して不溶解性を帶ふ るものと考へらる。

然し不溶解性化合物の構造は固より如何なる場 合に斯かる化合物を生じ、又如何にして之を除き 得るかは明かでない，是等は更に研究の餘地ある 8. 本編にては現在に於て一般的に應用し得る分 析方法の探究に止む。

發生法に於て標潐鐵使用に上る發生值の修正法 に關しては、鉄鐵の種領及性資により各發生率を 異にするものである以上. 一般分析法に應用し難 きは第 I 章 7 項に記述せる如くである。

\section{第 III 章 結 …論}

前述の各實驗に上り次の結論を得た，

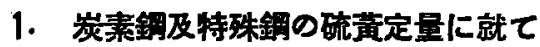

1）硝酸及醞酸に估る酸化法では第二鐵監溶液 より硫酸バリウムを沈溜する方法に依るる亦第二 鐵を第一鐵に還元した溶液より硫酸バリウムを沈 澱する方法でる其に一政した分析值を得られた。

2）操作の簡易、定量時間の短少及相當の熟練
等により誤差を少くし、常に正しき值を求娼易を 實用的見地よりして第二鐵監溶液より沈抜ささる 本實驗に行つた方法が、第二臷を第一鐵に還元し た溶液より沈澱する方法に比べて優れたすの人認 められる。

3）異つを操作に依る酸化法の分析値は一致し 且米國標潐試料では標潐局平均値上るよく一政す ること及是等の值が發生法實驗に於ける發生值と 张生嚗中殘留硫黃量との總計量とも近似のるて あること、英國各社との比校分析結果とよく一致 するとと等を綜合して硝酸及監酸に位る酸化法の 分析値は鋼中の全硫黃量と認められる上共に異つ た操作及異つた分析者に低り定量するも常に正確 なる俻を求め得られることを陁つを。

從つて硝酸及監酸次传る酸化法は一般炭素銅及 特殊鋼つ硫黃分析法として最も道當である。

4) 發生法は一般炭素鋼及特殊銅に對しては常。 に低分析值を示し傼に低炭素鋼の一部のるのに對， してのみ正確なる硫黄量を示すに過ぎない：

5）墢生法操作よしては燒鈍した試料を使用す ることが重要であつて、試料の憢鈍は發生值を良： くナる、酸湦度は濃監酸、稀監酸何れに依るる大 美なく、炭酸瓦斯或は水素瓦斯の通過及亞鉛アマ ルガムの使用は特に其の效果を認め難をる。生 現在の筑生操作では完全なる硫鱼量を，求め得ない 故を以て微少にても有效なりと考へられ、且合理 的な操作は之を施行すべきである，謂ふ意味に於 て探用するを適當と思的：

6）發生法で分析值として現はれない硫黄の太: 部分は常に墢生暴中に殘留することを筫證した。

7) 發生法几影響を及惊す元素としては， $\mathrm{Mo}$ ；

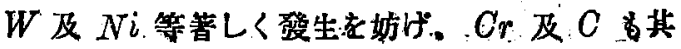


の含有量多き場合は發生值の低下を知つた。

8)、發生法では常に低値であるから、標潐鋼の 使用により發生值を修正して嘪際含方硫黄量の近 似值を求めやうとする便法に就ては、本研究に於 て鋼の成分異なる每に發生率異なり且其の組織の 如何によつては同じ成分の鋼でる：著しく發生率 異てする故を以て、一般に應朋することの不可 なるを實證した。

一從つて發生法は炭素鋼及特殊鋼の一般硫黃分析 法として不適當である。

\section{2. 銑鐵の硫黄定量に就て}

1) 發生法は銑鐵行對して低分析值を示す。

2) 發生值として現はれない硫黃の大部分は常 に發生晴中に殘留することを實證した。

3! 破生法で正しき分析值を得難きは鐵中で炭 素、硅素と硫黃との間に複雜なる化合物を構成 L 之が酸に對して不溶解性を带ぶるるのと想像せら れる。

4) 發生操作及標淮鐵使用に上る弡生値の修正 に關しては前項鋼に對すると同㥞、從て發生法は 一般銑鐵の硫黄分析法として不適當である。

5) 硝酸及監酸に依る酸化法は第二鐵監液より 硫酸ベリウムを沈澱させた䀛合及第二鐵を第一鐵 に還元した溶液より沈澱させた場合、其に本研究 に用ひた銑鐵試料に對しては大部低分析値を示し 僅に一部のるのに對してのみ正確な值を得られた に過ぎない、師ち本法では銑臷の種類により全硫 黄量を示す者上、全硫黄を示さない者とがある。

6) 硝酸及盘酸に依る酸化法で全硫黄量を示さ ないすのは操作中に取除加れる、黑鉛及珪酸の沈

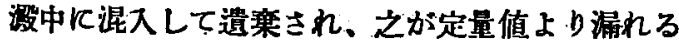
けのなるを筫證した。 之は發生法に於ける場合の站く、銑鐵中の不溶
解性硫黃化合物の存在により砧酸及罝酸で處亚す るも充分酸化が行はれ難いものと思はれる。

而して銅を弡生法で處瑟する場合の不㮞解性硫 黄化合物は、硝酸及蓪酸で容易に溶解酸化が行は れるにも拘はら市、銑鐵中に生する不溶解性硫黄 化合物は硝酸及監酸では分解しない。

7）若し强いて此の方法で銑鐵の硫黄量を定量 しやらとするには、尠くとも總ての試料に對して 黑鉛及珪酸の沈洷を處理して酸に不溶解性の硫黄 を定量せねばならぬ、然し之は工業分析的立場よ り見て適當な方法ではない。

故に硝酸及監酸に上る酸化法は鉃鐵の一般分析 法として不適當である。

8）本研究に於ては操作の簡易定量時間の短縮 と考虑して過酸化ソーダ及ソーダ灰 (1:1)の合 汶を使用する熔融酸化法を施行して銑鐵中の全硫 带量を求めを。

本法の定量值は發生法に於ける發生值と弡生嚗 中殘留硫黄量との總計量及确酸並に笽酸に依る酸 化法に於ける定量值と黑鉛珪酸中上り得た硫黃量 との總計量とよく一政し、米或標潐試料では標準 局平均値とも相一政し、銃鐵中の正確なる全硫黄 量なることを貝證した。

本アルカリ熔融酸化法は一般銑鐵の硫黃分析法 として適當である。

終に臨んで愍篤なる指導颙鞋を賜りたる㙒村海 軍造兵中佐从西泙海軍造兵中佐に厚く感謝の意を 表すると共に種々御瞂助を晹りたる部內訬賢に深 謝 L。及實驗に從事せる宗村繁明、楳本勳次兩氏， 凡謝意を表す。(終) 